\title{
Die bronteksouteur se bydrae tot die produksieproses van literêre vertalings 1
}

\author{
Carla-Marié Spies
}

Departement Afrikaans en Nederlands, Universiteit Stellenbosch

E-pos: carlamariespies@gmail.com

\section{Opsomming}

In hierdie artikel word 'n empiriese studie onderneem waarin die bydrae van die bronteksouteur in die produksieproses van literêre vertaling bestudeer word. Om hierdie doel te bereik, word drie produksieprosesse van literêre vertalings, To hell with Cronjé (Winterbach 2007b), My name is Vaselinetjie (Von Meck 2009a) en In bushveld and desert: A game ranger's life (Bakkes 2008) retrospektiewelik bestudeer deur elke proses te herkonstrueer om die veranderinge wat die bronteksouteurs aangebring het, asook hulle korrespondensie met ander produksieagente, bloot te lê. Hiervoor word manuskripte, notas en e-poskorrespondensie wat tydens elke produksieproses geproduseer is, kwalitatief ontleed. Antwoorde op semi-gestruktureerde vraelyste word ook as sekondêre data bestudeer om die produksieagente die geleentheid te bied om oor die produksieproses te reflekteer en aan die navorser dinamika en aangeleenthede wat nie uit die primêre data afgelei kon word nie, te verduidelik. Die ontleding word gedoen teen die agtergrond van relevante sosiologiese, vertaal- en redigeer/revisieteorie, en bevindinge van vorige studies wat in die agtergrondbespreking aangebied word. Uit die analise kan daar gesien word dat alhoewel al die produksieagente 'n beduidende rol in die produksie van 'n literêre vertaling speel, wil dit wel voorkom of die bronteksouteur die produksieagent is wat die meeste status/outoriteit in die produksieproses geniet en gevolglik ook die meeste mag het en invloed kan uitoefen. Verder kan daar gesien word dat die betrokkenheid van die bronteksouteur in al drie prosesse voordelig was om inhoudelike foute en verkeerde interpretasies uit te skakel en ander produksieagente se vrae te beantwoord. Daar word egter ook aangedui dat die betrokkenheid van die bronteksouteur in sekere opsigte nadelig vir die produksieproses kan wees, byvoorbeeld wanneer hy/sy die teks tot só 'n mate oorvertaal dat hy/sy as't ware die rol van die vertaler oorneem en/of ander produksieagente ondermyn, wat wedywering en 'n magswanbalans tot gevolg kan hê en die produksieproses kan strem.

Sleutelwoorde: Literêre vertaling, bronteksouteur, produksieproses, sosiologiese benadering tot vertaling, Bourdieu, redigering, revisie

\footnotetext{
${ }^{1}$ Hierdie artikel is gebaseer op navorsing uit 'n ongepubliseerde PhD-proefskrif, "Die wisselwerking tussen die agente betrokke by die publikasieproses van literêre vertalings" (Spies 2013).
} 


\section{The source text author's contribution to the production process of literary translations}

\section{Extended abstract}

During the production of a literary translation, a team of agents usually works very closely together to produce a target text. Therefore, the translation product cannot be attributed to the translator alone, as it is also influenced and shaped by other production agents.

This article centres on the way in which the source text author, as a production agent, could contribute to the production process of literary translations. For this purpose, three literary works of prose translated by the South African literary translator, Elsa Silke, are analysed, namely To hell with Cronjé (Winterbach 2007b), My name is Vaselinetjie (Von Meck 2009a) and In bushveld and desert: A game ranger's life (Bakkes 2008). The story in To hell with Cronjé takes place during the last weeks of the Anglo-Boer War (South African War, 1899-1902) and is about a group of Boer soldiers who help to bring a traumatised young man back to his parents' home. The story centres on the experiences of two of these men, the two natural scientists, Reitz Steyn and Ben Maritz. My name is Vaselinetjie is about a white child, Helena Bosman, who was thrown away as a baby and raised by a coloured couple. She is removed from her home when she is 10 years old and taken away to a children's home by welfare workers. There she is confronted by the "bad side" of society: drugs, gangs and cruel people. The novel tells the story of how she deals with and overcomes these circumstances. In bushveld and desert: A game rangers' life is a collection of short stories, of an autobiographical nature, about Chris and his experiences as a game warden, wildlife expert, traveller and soldier in Africa.

The production processes are analysed retrospectively by reconstructing them from manuscripts, notes and email correspondence produced during each process. This content analysis allows the researcher to observe the changes made to the translated texts by the source text authors and to reveal the extent and nature of these authors' collaboration and correspondence with other production agents during the process. Answers to semi-structured questionnaires are also used as additional data to provide production agents' reflections on the production processes and to explain aspects of the production process that are not clear from the data analysis. The production processes are analysed qualitatively and the results are presented against the backdrop of relevant sociological, translation and editing/revision theories, as well as previous studies on similar topics conducted in the field of translation studies.

Subsequently, inferences are made regarding the position of the source text author within the production process, his/her power/authority within this process, his/her interaction with other production agents and the influence of his/her involvement on the production process and the target text.

Based on the data analysis, it is determined that the source text authors were involved in the translation production process upon request by the publisher/commissioning editor and were given a large degree of freedom to be as involved in the production process as they wished to be. All three source text authors in this study were approached to answer other production agents' questions and notes, and questions were often directed at them. The type of amendments they made, or aspects they commented on during their revision processes, typically regarded transfer and content, and to a lesser extent style and language usage (compare Mossop's [2007] 
revision parameters). This was often done in collaboration with other production agents. The source text authors did not typically make amendments regarding structure and grammar. This was mainly done by the editors in the three processes analysed in this study. The translator also paid attention to these aspects. In the production processes of To hell with Cronjé and My name is Vaselinetjie the work that was performed by the source text authors could be seen as revision/editing as they worked through the entire text and made amendments to it. Furthermore, in To hell with Cronjé the source text author helped to translate and rewrite some sections. In My name is Vaselinetjie the source text author retranslated and rewrote or added text to a great extent. Both these source text authors also commented on the inputs of other production agents and answered their questions by means of emails and notes. They also posed questions to the other production agents. The source text author of In bushveld and desert: A game ranger's life was not as actively involved in the production of the target text, but was consulted throughout for inputs and to answer other production agents' questions and clarify meaning. Here and there, he rewrote small sections of the text and added some text where it was necessary to make the text more accessible to the target text reader. From the analyses, it could be seen that the source text author could be involved in the production process of literary translations in various capacities and to various extents.

In general, based on the three production processes analysed, it seems that the source text author is the production agent who has the most status in the production process as well as the most power/authority. The source text authors' power/authority within the production processes is illustrated by their influence on the selection of production agents, the publishers' and commissioning editors' respect for them and loyalty towards them by, for example, allowing them to have the last say in decisions that will influence the target text, and the fact that they were approached for advice and inputs throughout the processes.

From the analyses, it could be seen that the involvement of the source text authors was advantageous in all three production processes to correct mistakes in the content, eliminate incorrect interpretations and to answer other production agents' questions. In all three production processes analysed, the source text authors played an important role in this regard. This confirms the recommendation in Translation in practice (Paul 2009) that the source text author should ideally be involved in the production process of translations.

It is also shown that the involvement of the source text author could be harmful to the process, for example when (s)he retranslates the text to such an extent that (s)he takes over the role of the translator or undermines other production agents, as happened in the production process of My name is Vaselinetjie. The publisher or commissioning editor could act as a social mediator by trying to resolve the power imbalance, rivalry/competition and conflict that could occur during the production process (compare Bogic 2009) to ensure that cooperation takes place in a productive manner.

Therefore, it seems evident that the source text author should be careful not to retranslate or rewrite the translated text and, by doing that, take over the role of the translator and undermine his/her authority as the translation expert in the production process, and consequently cause power imbalances, rivalry/competition and conflict that strain the production process.

The opportunity for self-translation can, however, be created within the production process of literary translations, where the source text author translates the entire text him $/$ herself 
("self-translation", compare Cordingley 2013). Consequently, an interesting follow-up study would be to see how the production processes of translations differ between where the source text author is also the translator of his/her own text versus where a translator translates a text. Another interesting study would be to compare translation processes where the source text author is involved versus where the source text author is not consulted at all during the production process.

Keywords: Literary translation, source text author, production process, sociological approach to translation, Bourdieu, editing, revision

\section{Inleiding}

Tydens die produksieproses van 'n vertaling is daar gewoonlik 'n span agente wat nóú saamwerk om 'n doelteks te produseer. Die uiteindelike vertaalproduk word dus nie alleenlik deur die vertaler geskep nie, maar word ook deur ander produksieagente, byvoorbeeld die bronteksouteur, beïnvloed. Die invloed wat die onderskeie produksieagente op die proses en die produk uitoefen, is verder nie slegs tekstueel nie, maar ook sterk sosiologies van aard. Wolf (2007:1) beaam hierdie standpunt deur te noem dat "[a]ny translation, as both an enactment and a product, is necessarily embedded within social contexts". Hermans (1997:7) beklemtoon ook die sosiologiese aard van vertaling deur te sê dat daar binne die vertaalproses 'n veelvoud van norme en ander faktore is wat in konflik met mekaar verkeer. Hy noem dat die individue wat by 'n vertaalproses betrokke is, hulle tussendeur hierdie konflikterende aspekte moet maneuvreer. Binne die vertaalproses neem agente dus verskillende (mags)posisies in, vorm alliansies, kommunikeer oor sekere aspekte en maak keuses wat die produksie en ontvangs van 'n vertaling beïnvloed.

Hierdie artikel stel dit ten doel om die sosiologiese aspekte van die produksieproses van literêre vertalings te ondersoek deur te fokus op die rol van die bronteksouteur in die produksieproses van prosavertalings en die bydrae wat hy/sy tot die uiteindelike doelteks maak. Om te bepaal watter bydrae hierdie produksieagent tot die produksieproses (kan) lewer, word drie onderskeie literêre vertalings se produksieprosesse ondersoek.

\section{Sosiologiese aspekte van vertaling, revisie en redigering}

Tot so tien jaar gelede, is daar binne die vertaalwetenskap hoofsaaklik op die vertaalproduk gefokus en hoofsaaklik op die vertaler as die vernaamste, of selfs enigste, agent binne die produksieproses van vertalings. Namate die veld ontwikkel het, is al hoe meer klem geplaas op die produksie van vertalings asook die ander agente, byvoorbeeld bronteksouteurs en redigeerders, wat by die produksieproses van vertalings betrokke is.

Binne die funksionalistiese benadering tot vertaling plaas Holz-Mänttäri (in Nord 2001) byvoorbeeld reeds klem daarop dat vertaling 'n sosiale handeling en 'n kommunikatiewe proses is, nie net in die sin dat die doelteks met die doelteksleser kommunikeer nie, maar ook deurdat die agente (die rolspelers in hulle onderskeie rolle) betrokke by die vertaalproses met mekaar behoort te kommunikeer om die beste uiteindelike doelteks te verseker. 'n Mens kan hierdie teksbemiddelaars dus ook as sosiale bemiddelaars beskou. 
Teorieë uit die sosiologie as vakgebied word in vertaalteorie benut om sosiologiese teorieë van vertaling te ontwikkel en teorieë in die vertaalteorie wat sosiologiese aspekte aanraak, aan te vul.

Een van die sosiologiese teorieë wat toenemend in die vertaalteorie benut word, is Bourdieu se teorie oor die veld van kulturele produksie. Hy redeneer dat kulturele ware, soos boeke, geproduseer word in 'n bepaalde konteks, wat hy 'n "veld" noem. Binne hierdie veld, beïnvloed verskeie magte die produksieproses, onder andere habitus, doxa en kapitaal. Volgens Bourdieu (1977:72) is agente se "habitus" aspekte soos (aangeleerde) waardes en disposisies, wat gedrag, besluitneming, werkswyse, ensovoorts beïnvloed. "Doxa" is die oortuigings, norme, idees, ensovoorts wat gemeenskaplik is aan al die agente binne 'n bepaalde konteks. Dit kan beskou word as die reëls of norme wat binne daardie konteks geld (Bourdieu 2005:37). Dit sluit aan by Toury (2000:61) se beskouing van vertaling as 'n aktiwiteit wat deur norme beheers word. Hierdie norme bepaal weer die tipe en reikwydte van ekwivalensie/aanvaarbaarheid/ geskiktheid wat in werklike vertalings na vore kom. Norme is nie slegs van toepassing op die vertaling self nie, maar ook op die redigering en/of revisie van vertalings, aangesien redigering en revisie ook normgedrewe aktiwiteite kan wees deurdat dié aktiwiteite dikwels behels om 'n teks te verwerk deur taalreëls en -norme en stylreëls en -norme toe te pas (verwys byvoorbeeld Kotze en Verhoef 2001, en Van de Poel 2003). Volgens Bourdieu (1986) speel drie vorme van kapitaal in besonder 'n rol in die veld van kulturele produksie. Kulturele kapitaal behels onder meer die hulpbronne, byvoorbeeld kennis en vaardighede, wat'n agent self kan inwin of aanleer om hom/haar 'n voorsprong in die samelewing te gee (Bourdieu 1986:50), sosiale kapitaal is weer hulpbronne wat aan álle lede van'n groep beskikbaar is (Bourdieu 1986:51), en simboliese kapitaal sluit byvoorbeeld status, prestige, roem, mag, outoriteit, ensovoorts in, wat 'n agent vanweë sy/haar ánder kapitaal verwerf (Bourdieu 2002:171-183, 1993:75, 1986:47, 56). 'n Mens kan dit as die geïnstitusionaliseerde vorm van byvoorbeelde kulturele of sosiale kapitaal beskou.

Dié teorie oor die veld van kulturele produksie is nuttig om te verduidelik watter magte 'n rol speel in die produksie van kulturele ware en om die afsonderlike agente in die produksieproses te identifiseer. Mag is 'n kwessie wat ook prominent is in die vertaalteorie en word beklemtoon in veral die manipulasieteorie waarin daar geredeneer word dat álle vorme van vertaling ook 'n vorm van herskrywing (Lefevere 1992:vii) en, tot 'n mindere of meerdere mate, manipulasie behels (Hermans 1985:11). Manipulasie of herskrywing word deur Lefevere (1982, 1985, 1992) as 'n vertaalstrategie/-benadering aangebied, waarin hy beskryf hoe tekste deur middel van manipulasie en herskrywing aangepas word vir verskillende doelwitte. Hierdie manipulasie of herskrywing van tekste het die potensiaal om wrywing tussen produksieagente te veroorsaak en onderhandeling oor vertaalbesluite tot gevolg te hê.

'n Verdere veld wat met vrug benut kan word in die ontleding van die sosiologiese aspekte van vertaling en die produksieproses van vertaling, is redigeer- en revisieteorie. Wanneer die produksieproses van vertalings in geheel bestudeer word, moet hierdie aspekte ook bestudeer word, aangesien die werk wat produksieagente aan die vertaalde teks verrig, as redigering/revisie beskou kan word en omdat die redigeerders/reviseurs van die agente is waarmee daar in wisselwerking verkeer word tydens die produksieproses van vertalings.

Sowel vertalers as redigeerders en/of reviseurs werk met gemanipuleerde tekste, of manipuleer self die tekste en tree as teksbemiddelaars op. Daarom maak Mossop (2007) ook binne die 
redigeerteorie melding van die konsepte van herskrywing (rewriting) en aanpassing (adapting) en noem dat redigering behels om van 'n bestaande teks af te werk en veranderinge aan die bewoording daarvan aan te bring.

Redigering (editing) behels die verbetering van 'n teks, ook 'n vertaalde teks, deur hoofsaaklik nie terug te verwys na die bronteks nie. Daar bestaan tipes, of stadiums van, redigering, byvoorbeeld manuskripontwikkeling, omvattende redigering en kopieredigering, en Mossop (2007:198, 203) onderskei tussen verskillende vlakke van redigering, naamlik (1) Inhoudelike redigering: Nagaan van byvoorbeeld korrektheid van feite, (2) Strukturele redigering: Nagaan van fisiese en konseptuele struktuur, byvoorbeeld die verbetering van logiese volgorde en paragrafering, (3) Stilistiese redigering: Verbetering van stylaspekte soos register, skryfstyl en vloeiendheid, en (4) Kopieredigering: Nagaan van tegniese aspekte, byvoorbeeld die verbetering van spel- en taalfoute. In die bedryf word daar ook na redigering verwys as "taalversorging", "teksversorging", "teksredaksie" en "proeflees" (Carstens en Van de Poel 2010 en Mossop 2007) en ook soms as "hersiening" (review) (Pym 2011).

Revisie (revision) behels weer die nagaan van 'n vertaalde teks spesifiek met die doel om die bronteks en die doelteks te vergelyk en onder meer enige vertaalfoute uit te wys, of om byvoorbeeld'n teks nadat dit vertaal is, te herskryf om getrouer aan die bronteks te wees, oftewel 'n "akkurater" vertaling te lewer. Dit kan ook behels om die vertaling aan te pas om beter met die doelteksleser te kommunikeer. Mossop (2007) onderskei tussen 12 revisieparameters wat spesifiek betrekking het op die revisie van vertaalde tekste. Hy verdeel die 12 parameters in vier hoofkategorieë, naamlik (1) Oordrag: Probleme met oordrag van betekenis, (2) Inhoud: Probleme met inhoud, (3) Taal (en styl): Probleme met taalkundige en stilistiese aspekte, en (4) Aanbieding: Probleme met fisiese aanbieding. Mossop (2007) noem dat hierdie parameters ook toegepas kan word op die redigering van "oorspronklik geskrewe" tekste (net soos die vlakke van redigering toegepas kan word op die revisie van vertaalde tekste) en noem dat eintlik slegs die eerste twee parameters, naamlik akkuraatheid en volledigheid, wat binne die kategorie "oordrag" val, spesifiek net op die revisie (of redigering) van vertalings van toepassing is. Die revisieproses sal ook noodwendig 'n vorm van redigering insluit. Mossop (2007) definieer revisie as die nagaan van 'n konsepvertaling deur spesifiek 'n tweede (ander) vertaler, maar by literêre vertalings is ander agente dikwels ook verantwoordelik vir hierdie proses, soos daar in hierdie artikel getoon sal word. Daar word ook in die bedryf na revisie verwys as "gehaltebeheer" (quality control), "hersiening" (review) (Van Rensburg 2012 en Pym 2011) en selfs "redigering" (editing) (Pym 2011).

Behalwe vir die tekstuele dimensie van redigering/revisie, soos korrekte skryfwyse, spelling, sintaksis, nakoming van taalreëls, ens. (Mossop 2007, Carstens en Van de Poel 2010) het hierdie take ook 'n sterk sosiologiese dimensie en redigeerders en reviseurs, asook die persone wat hierdie take verrig, byvoorbeeld bronteksouteurs, kan ook beskou word as sosiale bemiddelaars omdat die herbewerking, afronding en korrigering van die vertaalde teks dikwels wisselwerking en korrespondensie tussen die produksieagente tot gevolg het (verwys na Holz-Mänttäri, aangehaal in Nord 2001).

Judith Tarutz (1992:7) verduidelik byvoorbeeld dat die literêre redigeerder gewoonlik in hegte verwantskap met die skrywer werk. Sy sê "although the literary editor may be authorized to change the manuscript without the writer's permission, he or she normally effects changes through negotiation" (Tarutz 1992:7, eie beklemtoning). Hierdie onderhandelingsproses 
waarna Tarutz verwys, vind ook plaas tydens die revisie en redigering van vertaalde literêre tekste. In die boek Translation in practice (Paul 2009:10,29) word daar genoem dat dit nuttig kan wees en as "goeie praktyk" beskou kan word as die vertaler in oorleg met die bronteksouteur werk sodat hy/sy byvoorbeeld vrae kan beantwoord en verduidelikings kan verskaf. Daar word aanbeveel dat die vertaler aan die bronteksouteur bekendgestel moet word (via e-pos, 'n foonoproep of persoonlik) sodat 'n kommunikasiekanaal gevestig kan word. Volgens die boek kan redakteurs dan van die vertaler se verbale vaardighede gebruik maak om suksesvol met die bronteksouteur te kommunikeer oor hoe die projek vorder. Daar word verder genoem dat dit ook belangrik is dat die outeur gemaklik moet voel daarmee om die vertaler se navrae te beantwoord en om dele van die bronteks te verduidelik wat nie heeltemal duidelik is nie. Verder beveel die boek aan dat veranderinge wat aangebring word om die vertaling meer verstaanbaar te maak, aan die bronteksouteur voorgelê moet word (Paul 2009:11).

Oor die reviseur (en dit sluit in die bronteksouteur wat revisiewerk verrig) se verhouding met die vertaler, merk Mossop (2007:175) op dat veranderinge wat aangebring word tydens die revisie van ander se werk, interpersoonlike verhoudings kan strem. Daarom waarsku hy teen ongeregverdigde veranderinge wat deur enige party aan 'n teks aangebring word. Om dit reg te kry, sê hy dat 'n mens die geldigheid van verskillende benaderings (wat van jou eie kan verskil) moet kan erken en besef dat daar 'n reeks aanvaarbare vertaalmoontlikhede of -strategieë bestaan. Hy sê verder dat iemand wat aan 'n teks werk daarteen moet waak om sy/haar eie interpretasie van 'n teks daarop af te dwing en slegs taal- en stilistiese veranderinge moet aanbring wanneer hulle geregverdig is deur die kommunikatiewe doelwit (Mossop 2007:176). Agente moet dus daarteen waak dat hulle vooropgestelde idees en disposisies (verwysend na Bourdieu) nie 'n rol in hulle besluitneming speel wanneer hulle aan ander se tekste werk nie. Die toepassing van hierdie beginsel raak egter gekompliseerd wanneer 'n bronteksouteur revisiewerk verrig aan sy/haar eie teks wat vertaal is. Aan die een kant, werk hy/sy aan sy/haar eie skepping en aan die ander kant werk hy/sy aan die vertaler se produk. Mossop (2007:177) noem ook dat daar altyd gevalle sal wees waar'n vertaler (byvoorbeeld) nie sal saamstem met veranderinge wat aangebring word nie, selfs al word minimale veranderinge aangebring en verduidelikings vir die veranderinge verskaf. Onderhandeling, wrywing en dispute sal dus onvermydelik deel van 'n produksieproses van vertalings vorm wanneer meer as een produksieagent daarby betrokke is.

\section{Bestaande navorsing}

Om op die sosiologiese aspekte van vertaling te fokus, en veral die produksieproses van 'n vertaling van aanvang tot einde te analiseer, is tans 'n onderwerp waaraan baie aandag in die vertaalkunde gewy word, soos duidelik blyk uit publikasies soos Constructing a sociology of translation (Wolf en Fukari 2007) en kongresse soos Collaborative translation: From antiquity to the Internet (International Association of Translation and Intercultural Studies [IATIS] 2014). Buzelin (2007:141) merk op dat hierdie tipe studie belangrik is, aangesien die dokumentering van 'n vervaardigingsproses ' $n$ mens in staat stel om die rol van die agente in die produksieproses beter te kan analiseer en ook te kan kyk na die verskillende stadia van die proses, byvoorbeeld redaksionele en revisiewerk wat verrig word aan die vertaalde teks. Sy sê dit word egter min gedoen, in teenstelling met die kreatiewe (artistieke en wetenskaplike) prosesse wat ruimskoots gedokumenteer word. Sy noem drie moontlike redes hiervoor: (1) die vertaler se "legendary invisiblity" (verwysend na Venuti 1995, wat beweer dat die literêre vertaler ten onregte meestal "onsigbaar" is in 'n doelteks deurdat sy/haar intervensie nie in die 
vertaalproduk waargeneem/raakgesien kan word nie en die vertaling deur die doeltekslesers beskou word as 'n oorspronklik geskrewe werk deur die bronteksouteur - verwysend na domestikering as 'n vertaalstrategie), (2) die skynbare sekondêre status van die tekste wat deur vertalers produseer word, of bloot (3) omdat die vertaal- of produksieproses, in vergelyking met verspreiding en resepsie, binne die privaat sfeer van die uitgewery val en dus moeiliker is om te bestudeer. Gevolglik was daar tot onlangs toe 'n groot leemte in die vertaalwetenskap wat betref empiriese studies om die sosiologiese aspekte van die produksieproses van vertalings te illustreer.

Etlike studies is egter onlangs uitgevoer waarin daar gefokus is op die produksieproses van vertalings en die agente wat by hierdie proses betrokke is. 'n Paar van hierdie studies waarin die bronteksouteur ook as agent ondersoek is, word vervolgens opsommenderwys bespreek.

In haar studie oor die produksieproses van 'n vertaling het Bogic (2009) die produksieproses van die Engelse vertaling van Simone de Beauvoir se filosofiese boek Le deuxième sexe (The second sex, 1953) ondersoek deur die verhouding tussen veral die vertaler en die uitgewer (maar ook ander agente, byvoorbeeld die bronteksouteur) tydens die produksieproses van die vertaling te bestudeer. Sy het daarvoor die briefwisseling tussen die vertaler en uitgewer as primêre data geanaliseer. Om dit aan te vul, is daar ook gekyk na resensies van hierdie vertaling deur verskeie kritici. Sy het tot die gevolgtrekking gekom dat die verhouding tussen agente in die vertaalproses problematies en gekompliseerd was as gevolg van die vertaler se gebrekkige filosofiese kennis, die besturende redakteur se aandrang daarop om die vertaling te sny en te vereenvoudig, die uitgewery se intensie om die boek se wetenskaplike "kasjet" te beklemtoon en die bronteksouteur se gebrekkige samewerking (Bogic 2009:97). Daar was dus voortdurend spanning tussen die betrokke agente en hulle agentskappe, en hulle vooropstellings en idees met die vertaling. Dit het 'n wedywering om mag tot gevolg gehad wat uiteindelik 'n negatiewe invloed op die doelteks en sy ontvangs uitgeoefen het en'n nuwe vertaling in Engels genoodsaak het (Bogic 2009:97, 98).

Letawe (2014) het die wisselwerking tussen die Duitse skrywer Günter Grass en sy vertalers bestudeer. Hiervoor is twee tipes dokumentasie ontleed: Die een stel dokumente is dié wat verband hou met die seminare wat Grass telkens voor die publisering van 'n vertaling met sy vertalers gehou het. Die doel van hierdie seminare was om probleme in die vertalings aan te spreek en die gehalte daarvan te verbeter. Die ander stel dokumente was van die korrespondensie wat sy in die hande kon kry wat tussen Grass en sy vertalers, uitgewers en redigeerders plaasgevind het. Sy het onder andere gekyk na die interaksie tussen die outeur en sy vertalers en die uitdagings bespreek wat tipies tydens die seminare aan bod gekom het, byvoorbeeld oordrag van dialek en woordspeling. Sy het ook 'n vergelyking getref tussen die verskillende doeltekste (Amerikaanse Engels, Frans en Nederlands) van dieselfde bronteks en merk byvoorbeeld op dat die strategie ten opsigte van onverstaanbare of moeilik verstaanbare konsepte in die teks verskillend deur die verskillende vertalers benader is. In die Engelse tekste word daar geëkspliseer of verduidelik, in die Franse tekste nie en in die Nederlandse tekste word hierdie verwysings bloot uitgelaat. Sy kom verder tot die gevolgtrekking dat hierdie interaksie tussen Grass en die vertalers 'n manier vir hom was om die oordrag van sy werk in die buiteland te beheer. Sy merk ook op dat die interaksie tussen die outeur en die vertalers ook die vertalers meer sigbaar (in vergelyking met die onsigbaarheid van die vertaler soos deur Venuti 1995, gepostuleer) gemaak het deurdat hierdie seminare geadverteer is en oor verslag gelewer is en dat die outeur in gesprek met die vertalers getree het en hulle insette verwelkom 
het. Die mag en invloed wat die bronteksouteur op die doelteks kan hê, word dus sterk deur hierdie studie beklemtoon.

Jansen (2014) is tans besig om 'n vraelys te ontwikkel om die interaksie tussen die verskillende produksieagente tydens die produksieproses van 'n vertaling te bestudeer. Die konteks waarin sy werk, is die vertaling van literêre tekste in die Skandinawiese lande Denemarke, Swede en Noorweë. Sy wil graag drie tipes samewerking ondersoek, naamlik die wisselwerking tussen die vertaler en (1) die bronteksouteur, (2) die redakteurs, en (3) ander vertaalkollegas. Haar hoofdoel is om vas te stel hoe die vertalers reageer op ander agente se "intervensie". Haar hooffokus sal wees op die wisselwerking tussen die vertaler en bronteksouteur en deur middel van die vraelys wil sy data insamel oor byvoorbeeld die vertaalspesifikasie (brief) en ander dialoog wat tussen die bronteksouteur en die vertaler plaasvind. Sy vra vrae soos: "Hoe reageer vertalers op outeurs se instruksies?", "Vind vertalers die vertaalspesifikasie van die outeurs nuttig?" en "Beskou vertalers die outeurs se hulp as 'n positiewe intervensie of as 'n poging om hoe hulle die teks lees en die vertaalkeuses wat hulle maak in 'n sekere rigting te stuur?" Sy wil ook graag vasstel of dit moontlik is om die (ekstratekstuele) stem van die outeur in die vertaalproduk te bespeur.

\section{Doelstelling van hierdie studie}

Om die korpus van sosiologiese studies oor vertaling aan te vul, en 'n bydrae te maak tot die navorsing oor die wisselwerking tussen produksieagente tydens die produksieproses van literêre vertalings, word die interessante dinamika tussen die verskillende agente wat aan 'n vertaling werk, gevolglik in hierdie artikel ondersoek. Daar word spesifiek gefokus op die bronteksouteur se bydrae tot die produksieproses van literêre vertalings ten opsigte van sy/haar wisselwerking met ander produksieagente en sy/haar insette in die doelteks. Daar word gekyk na hoe die bronteksouteur se insette 'n impak op die interaksie tussen produksieagente en die verloop van die produksieproses kan hê.

\section{Metodologiese raamwerk}

Om die betrokkenheid van die bronteksouteur by die produksieproses van literêre vertalings te ondersoek, word 'n empiriese studie uitgevoer waarin die wisselwerking tussen produksieagente van literêre vertalings blootgelê word. Die produksieagente verwys na die persone wat by die kernproduksieproses van die doelteks betrokke is en sluit die uitgewers/opdraggewende redakteurs, bronteksouteur, vertaler en redigeerders/reviseurs/proeflesers in. Daar word ook na die tekste gekyk wat deurgaans 'n rol in die produksieproses gespeel het. Sodanige tekste is byvoorbeeld die vertaalspesifikasie, die bronteks, e-posse, notas en ander vorme van korrespondensie tussen die produksieagente.

\subsection{Data-analise}

Die volgende tekste word as primêre data in dié studie ontleed om die wisselwerking tussen produksieagente te bestudeer: 
- Brontekste en doeltekste van die voorbeeldmateriaal.

- Verskillende weergawes (manuskripte [MS]) van die vertalings deur die loop van elke produksieproses.

- Parateks in die bron- en doeltekste, naamlik die buiteblaaie, die titelbladsye, die kolofonbladsye en die woordelyste in die onderskeie boeke.

- Metateks in die vorm van geskrewe korrespondensie tydens die produksieproses: Notas wat deur die loop van die proses deur die onderskeie produksieagente geskryf is en e-posse wat deur die loop van die proses deur produksieagente aan mekaar gestuur is.

Antwoorde op semi-gestruktureerde vraelyste word ook as aanvullende data bestudeer. Hierdie vraelyste is beantwoord deur die uitgewers/opdraggewende redakteurs, bronteksouteurs, vertaler, redigeerders/reviseurs/proeflesers en het hulle die geleentheid gebied om oor die produksieproses te reflekteer en aan die navorser dinamika en aangeleenthede wat nie uit die primêre data afgelei kon word nie, te verduidelik.

Daar word histories/retrospektief te werk gegaan (na aanleiding van Bogic 2009), deur die produksieprosesse van die drie literêre vertalings wat reeds afgehandel is, te rekonstrueer deur van die bostaande data gebruik te maak. 'n Kwalitatiewe analise word gevolglik van die data gemaak om beskrywende afleidings oor die betrokkenheid van die bronteksouteur by die produksieproses van literêre vertalings te maak.

\subsection{Afbakening}

Agorni (2009:129) beskryf die aanwending van lokalisme, na aanleiding van Tymoczko, as 'n manier om spesifieke vertaalverskynsels na te vors sonder om binne individuele gevallestudies té veralgemenend te raak. Dit behels dat 'n deeglike rekonstruksie van agente se sosiale, linguistiese, historiese en kulturele kontekste verskaf word. Hierdie studie is gevolglik gelokaliseer binne NB-Uitgewers, 'n prominente Suid-Afrikaanse uitgewery.

Verder is die studie beperk tot drie spesifieke produksieprosesse van vertaalde literêre prosa om 'n diepte-ontleding van die data te bemoontlik. Daar is na meer as een produksieproses gekyk om wel diversiteit te verseker sodat moontlike tendense geïdentifiseer kan word.

Die produksieprosesse van die drie literêre vertalings wat in hierdie studie ondersoek word, word in tabel 1 aangebied. Die prosesse wat bestudeer is, is dié van die produksie van To hell with Cronjé (Winterbach 2007b), My name is Vaselinetjie (Von Meck 2009a) en In bushveld and desert: A game ranger's life (Bakkes 2008). 
Tabel 1: Voorbeeldmateriaal en besonderhede daarvan

\begin{tabular}{|c|c|c|c|}
\hline & $\begin{array}{l}\text { BT: }{ }^{2} \text { Niggie } \\
\text { (Winterbach 2007a) } \\
\text { DT: }{ }^{3} \text { To hell with } \\
\text { Cronjé (Winterbach } \\
\text { 2007b) }\end{array}$ & $\begin{array}{l}\text { BT: Vaselinetjie } \\
\text { (Von Meck 2009b) } \\
\text { DT: My name is } \\
\text { Vaselinetjie (Von } \\
\text { Meck 2009a) }\end{array}$ & $\begin{array}{l}\text { BT: 'n Keur uit die } \\
\text { Stoffel-verhale (Bakkes } \\
2004 \mathrm{a}, 2004 \mathrm{~b}, 2006,2007) \\
\text { DT: In bushveld and desert: } \\
\text { A game ranger's life (Bakkes } \\
2008)\end{array}$ \\
\hline Genre & Fiksie: Roman & $\begin{array}{l}\text { Fiksie: Jeugroman / } \\
\text { jong volwasse-fiksie }\end{array}$ & $\begin{array}{l}\text { Fiksie met 'n outobiografiese } \\
\text { inslag ("faction"): } \\
\text { BT: Episode uit roman en } \\
\text { verhale uit } \\
\text { kortkortverhaalbundels, DT: } \\
\text { kortverhaalbundel }\end{array}$ \\
\hline $\begin{array}{l}\text { Skrywer/bronteks- } \\
\text { outeur }\end{array}$ & Ingrid Winterbach & Anoeschka von Meck & Christiaan Bakkes \\
\hline Vertaler & Elsa Silke & Elsa Silke & Elsa Silke \\
\hline $\begin{array}{l}\text { Ander } \\
\text { produksieagente } \\
\text { betrokke }\end{array}$ & $\begin{array}{l}\text { Uitgewer, reviseur, } \\
\text { redigeerder }\end{array}$ & $\begin{array}{l}\text { Opdraggewende } \\
\text { redakteur, redigeerder }\end{array}$ & $\begin{array}{l}\text { Uitgewer, samesteller, } \\
\text { redigeerder }\end{array}$ \\
\hline Uitgewery & $\begin{array}{l}\text { Human \& Rousseau } \\
\text { Fiksie, NB-Uitgewers }\end{array}$ & $\begin{array}{l}\text { Tafelberg Kinder- en } \\
\text { jeugboeke, } \\
\text { NB-Uitgewers }\end{array}$ & $\begin{array}{l}\text { Human \& Rousseau Fiksie, } \\
\text { NB-Uitgewers }\end{array}$ \\
\hline $\begin{array}{l}\text { Bron- en } \\
\text { doeltekstaal }\end{array}$ & BTT: ${ }^{4}$ Afr. DTT: $:^{5}$ Eng. & BTT: Afr. DTT: Eng. & BTT: Afr. DTT: Eng. \\
\hline $\begin{array}{l}\text { Eerste jaar van } \\
\text { publikasie }\end{array}$ & $\begin{array}{l}\text { BT: } 2002 \\
\text { DT: } 2007\end{array}$ & $\begin{array}{l}\text { BT: } 2004 \\
\text { DT: } 2009\end{array}$ & $\begin{array}{l}\text { BT: } 1998-2007 \\
\text { DT: } 2008\end{array}$ \\
\hline
\end{tabular}

To hell with Cronjé speel af tydens die laaste paar weke van die Anglo-Boereoorlog (Suid-Afrikaanse Oorlog, 1899-1902) en gaan oor 'n groepie Boerekrygers wat 'n getraumatiseerde jong man terug na sy ouerhuis neem. Die roman fokus op die ervaringe van twee van hierdie mans, twee natuurwetenskaplikes, Ben Maritz en Reitz Steyn. My name is Vaselinetjie gaan oor 'n wit weggooikind, Helena Bosman (Vaselinetjie), wat deur 'n bruin paartjie grootgemaak is en dan op die ouderdom van tien jaar deur welsynwerkers weggeneem word na 'n kinderhuis. Hier maak sy kennis met die "slegte kant" van die samelewing - dwelms, bendes en ongenaakbare mense - en daar word vertel hoe sy hierdie omstandighede trotseer en uiteindelik oorkom. In bushveld and desert: A game rangers' life is 'n versameling kortverhale met 'n outobiografiese inslag oor Chris en sy ervarings as wildbewaarder, kenner van die bosveld, reisiger en soldaat in Afrika.

\section{Resultate en bespreking}

Vervolgens word afleidings wat gemaak is uit die data wat ontleed is per gerekonstrueerde produksieproses aangebied. In die gevolgtrekking word hierdie afleidings saamgevat in 'n vergelykende bespreking van die betrokkenheid van die bronteksouteur in die produksieproses van literêre vertalings.

\footnotetext{
${ }^{2} \mathrm{BT}=$ Bronteks

${ }^{3} \mathrm{DT}=$ Doelteks

${ }^{4} \mathrm{BTT}=$ Brontekstaal

${ }^{5}$ DTT $=$ Doeltekstaal
} 
Die weergawes van die manuskripte wat ontleed is, word hieronder aangebied. Afkortings word aan elke manuskrip verskaf, wat deurgaans in die bespreking gebruik word om tussen die verskillende weergawes van die tekste te onderskei.

Vyf weergawes van die roman was betrokke by die produksieproses van To hell with Cronjé:

- Bronteks (BT): Afrikaanse bronteks, soos gepubliseer

- Manuskrip 1 (MS1): Konsepvertaling deur die vertaler

- Manuskrip 2 (MS2): Konsepvertaling gereviseer deur die bronteksouteur

- Manuskrip 3 (MS3): Konsepvertaling geredigeer/gereviseer deur die vertaler nadat die bronteksouteur dit geredigeer/gereviseer het

- Doelteks (DT): Engelse doelteks, soos gepubliseer - nadat dit geredigeer/gereviseer en geproeflees is

Sewe weergawes van die roman was betrokke by die produksieproses van My name is Vaselinetjie:

- Bronteks (BT): Afrikaanse bronteks, soos gepubliseer

- Manuskrip 1 (MS1): Konsepvertaling deur die vertaler

- Manuskrip 2 (MS2): Konsepvertaling gereviseer en verwerk deur die bronteksouteur

- Manuskrip 3 (MS3): Konsepvertaling geredigeer/gereviseer en van die bronteksouteur se veranderinge geïnkorporeer deur redigeerder

- Manuskrip 4 (MS4): Revisie deur die bronteksouteur en voorstelle deur die vertaler oor MS3

- Manuskrip 5 (MS5): Revisie deur die bronteksouteur van MS3 en MS4

- Doelteks (DT): Engelse doelteks, soos gepubliseer

Vyf weergawes van die kortverhale plus twee weergawes van die proefvertaling was betrokke by die produksieproses van In bushveld and desert: A game ranger's life:

- Bronteks (BT): Bronteks: Verhale uit die Afrikaanse brontekste, soos gepubliseer

- Proefvertaling 1 (PV1): Proefvertaling deur die vertaler

- Proefvertaling 2 (PV2): Proefvertaling geredigeer/gereviseer deur die uitgewer

- Manuskrip 1 (MS1): Konsepvertaling deur die vertaler

- Manuskrip 2 (MS2): Konsepvertaling geredigeer/gereviseer deur die samesteller (met inkorporering van die bronteksouteur se aanbevelings)

- Manuskrip 3 (MS3): MS 2 geredigeer/gereviseer deur die redigeerder (met die bronteksouteur se kommentaar geïnkorporeer)

- Doelteks (DT): Engelse doelteks, soos gepubliseer

Verteenwoordigende aanhalings uit die voorbeeldmateriaal en vraelyste word gegee om die afleidings wat gemaak word, te staaf. 


\subsection{To hell with Cronjé}

\subsubsection{Verloop van die produksieproses}

Volgens die uitgewer van To hell with Cronjé word daar baie ag geslaan op die bronteksouteur, Ingrid Winterbach, se aanbevelings tydens die produksieproses van haar vertalings (Potgieter 2011 b). Hierdie erkenning wat sy geniet, is waarskynlik afkomstig van, eerstens, haar hoë status in die Suid-Afrikaanse literêre kanon, nie net as skrywer nie, maar ook as vertaler van haar eie werk, as gevolg van haar lang publikasierekord en verskeie pryse wat sy al verower het, onder meer die Hertzogprys en SALA-toekenning vir literêre vertaling (kulturele kapitaal wat geïnstitusionaliseer is in simboliese kapitaal [Bourdieu 2002, 1993, 1986]) en, tweedens, omdat sy haarself al as goeie medewerker in vorige produksieprosesse bewys het (Potgieter 2011b). Daarom was sy intensief betrokke by die skep van To hell with Cronjé en haar menings het swaar geweeg. Die uitgewer het byvoorbeeld in 'n e-pos aan die redigeerder opgemerk:

Both [the writer] and [the translator] actually "weigh" every word they use. I think the editor has to be aware of that, and mainly correct obvious mistakes or query words or phrases that don't work well or feel too literal, etc. I'd like you to do the editing in track changes, because the text has to go back to the author for considering the changes and queries and suggestions. You could either insert and highlight any queries you have in the text, or do them in caps in brackets - whatever stand out more. I hope you won't mind working like that?

\section{$[\ldots]$}

[The author] has a very distinctive style of writing, have you read anything by her? If not, I thought it might be useful if I lend you a copy of The Elusive Moth to read beforehand, if you have time. Let me know (eie beklemtoning).

Hierdie opmerkings getuig daarvan dat daar in oorleg met die bronteksouteur gewerk is (vergelyk Mossop 2007) en dat sy dikwels 'n finale sê oor besluite gehad het. Dit getuig wel ook van respek vir die vertaler, aangesien die uitgewer ook noem dat die vertaler noukeurig oor haar besluite nadink. Die tweede helfte van die opmerking bevestig die status van die bronteksouteur (vergelyk Bourdieu 1986) as skrywer en die feit dat die uitgewer dit belangrik beskou dat die styl van die bronteksouteur behoue moet bly in die doelteks (vergelyk Mossop 2007:176).

Die bronteksouteur het ook 'n invloed uitgeoefen op die keuse van medewerkers. Die vertaler en redigeerder is gekies op grond van hulle goeie reputasie om Winterbach se werk te vertaal en te redigeer (Potgieter 2011b) en die uitgewer het in oorleg met die bronteksouteur ' $\mathrm{n}$ proefvertaling van die vertaler aangevra alvorens Niggie vertaal is. Nadat die proefvertaling voltooi en gekeur is, het die vertaler die boek verder vertaal en die teks vir die bronteksouteur aangestuur, vergesel van 'n vertaalnota waarin die vertaler 'n paar vrae aan die bronteksouteur gestel het waaroor sy tydens die vertaling gewonder het. Die bronteksouteur het dié vertaling verbeter en aangepas en ook soms dele herskryf of hervertaal.

'n Voorbeeld van 'n gedeelte waar die bronteksouteur help vertaal het, is 'n teksgedeelte oor 'n woordspeletjie wat deur die karakters in die boek gespeel word. 
Vervolgens 'n uittreksel uit een van die woordspeletjies:

BT: Hulle kyk op na die voëls in die lug.

"Aasvoëloë," sê Reitz, "waarmee hulle ons dophou."

"Aasvoëlvet, as geneesmiddel," sê Ben.

"Aasvoëlkrans," sê Reitz, "waar aasvoëls broei."

"Aasvoëltee," sê Ben, "laat die diere vrek."

"Aasvreter," sê Reitz, "dier wat aas vreet."

"Aaskewer," sê Ben, "kewertjie wat op dierlike reste leef."

"Bokdrol," sê Reitz, "die drol van 'n bok."

"Bokdruiwe," sê Ben, "verwant aan die bokduwweltjie."

"Bokmelk," sê Reitz, "die melk van 'n bok."

"Bokdrolbessie," sê Ben, "die sap is soet en klewerig."

"Daspis," sê Reitz. "Die pis van ’n das."

"Jaspis," sê Willem, "strate van jaspis en goud."

"Hemel, ou Willem!" sê Ben. "Hemelkruid - met sy soet geur."

"Hemelhoog," sê Reitz, "so hoog soos die hemel."

"Hawer," sê Willem, "perde se voer."

"Gawer," sê Ben, "gawer as wat Peternella was, kon niemand ooit wees nie."

Selfs Willem glimlag (Winterbach 2007a:29).

Winterbach se eiesoortige taalgebruik, en veral hierdie tipe woordspeletjies, het 'n besondere uitdaging aan die vertaler gebied. Om die woordspeletjie te vertaal in dieselfde toon en met woordkeuses wat by die tema en konteks van die roman inpas, was moeilik. Die vertaler het genoem dat sy by die woordspeletjies aanvanklik die woordreeks bloot vertaal het en dat die alfabetiese progressie (en met ander woorde ook die hele speletjie) toe verlore geraak het. Sy sê wat ook hier uitdagend was, was dat die vertaler in gedagte moet hou dat die protagoniste, Ben en Reitz, vanuit hulle eie belangstellingsveld as natuurwetenskaplikes praat (Silke 2011b).

Oor haar tweede poging het die vertaler die volgende aan die bronteksouteur geskryf:

Ek stuur maar vir jou my woordspeletjie, interessantheidshalwe. Hierdie keer is dit wel alfabeties - ek kry nou nog skaam oor ek dit misgekyk het in die eerste poging. ${ }^{6}$

Ek het die logika van die Afrikaans probeer volg vanaf aasvoël na diere wat vrek na dier wat aas vreet na Ben se kewer wat op dierlike reste leef. Daarna het dit vir my gelyk of Reitz fokus op dierlike reste/uitskeidings met sy verwysings na drol - melk - pis. Dis toe wat ek probeer doen het - miskien te geforseerd. Ek weet nie of jy die tyd wil spandeer om na myne te kyk nie. As jy tevrede is om joune net so te hou, dan is ek ook gelukkig en skrap dadelik hierdie poging (eie beklemtoning).

Die vertaler noem in haar laaste sin dat sy tevrede daarmee is as die bronteksouteur se weergawe van die woordspeletjie in die doelteks gebruik word. Sy toon hierdeur respek en agting vir die bronteksouteur se gesag, status en outoriteit as magsagent in die produksieproses en laat haar as't ware toe om as medevertaler/herskrywer (verwys na Lefevere 1992, Hermans 1985 en Mossop 2007) in die produksieproses op te tree. Om te reageer op twee van die vrae wat Jansen (2014) stel: In hierdie geval, kan 'n mens sien dat die vertaler positief op die bronteksouteur se instruksies reageer en haar insette/hulp as konstruktief beskou. Die weergawe van spesifiek die

\footnotetext{
${ }^{6}$ In die konsepvertaling.
} 
eerste woordspeletjie is hoofsaaklik die bronteksouteur se skepping. Sy gebruik haar digterlike vryheid en herskryf hierdie woordspeletjie soos volg:

MS2: There must be a cliff nearby, Ben remarks, watching the birds.

"Buzzard," Reitz says, "predatory bird."

"Bird of prey, which hunts animals for food," says Ben.

"Bone, , [sic]" says Reitz, "the remains after death."

"Botfly," says Ben, "dipterous fly with stout body."

"Carrion," says Reitz, "dead, putrefying flesh."

"Carrion crow," says Ben, "bird feeding mainly on carrion."

"Devonian," says Reitz, "geological period "Devil," says Willem, "lord of the kingdom of evil."

"Devil's coach-horse," says Ben, "large rove beetle."

"Goldfield," says Reitz, "[sic] district where gold is found."

"Gold," says Willem, "streets of jasper and gold."

"Good heavens, old Willem!" Ben exclaims. "goldcrest, with its heavenly warbling [sic]."

"Heavenly body," says Reitz, "celestial object."

"Hay," says Willem, "to feed the horses."

"Helpful," says Ben, "more helpful than Peternella was one could not hope for."

Even Willem smiles.

Die vertaler het nadat die bronteksouteur die konsepvertaling gereviseer het, haar veranderinge in MS Word aanvaar (accept) en deur die teks gewerk deur dit te reviseer (in die MS Worddokument deur middel van spoorveranderinge [track changes]). Sy het dus ook, soos die bronteksouteur, in die hoedanigheid van reviseur/redigeerder opgetree. Sy het daarna per nota kommentaar gelewer oor die grootste kwessies wat haar opgeval het, verduidelik hoe sy te werk gegaan het en van die besluite wat sy geneem het verduidelik/motiveer. Hierdie opmerkings dui daarop dat sy die ander produksieagente respekteer en belangrik genoeg ag om belangrike besluite aan hulle te korrespondeer. Dit korreleer met Mossop (2007), Tarutz (1992) en Paul (2009) se aanbevelings dat besluite aan ander produksieagente gekommunikeer moet word en veranderinge geregverdig moet word.

Heelwat uitruiling van idees en oplossings vir vertaalprobleme is tussen die bronteksouteur en die vertaler tydens die vertaalproses self hanteer en hulle het dikwels direk met mekaar (met ander woorde nie altyd deur die uitgewer as tussenganger nie) gekommunikeer. Dit stem ooreen met wat Letawe (2014) oor Grass opmerk oor die bronteksouteur wat direk met sy vertalers geskakel het, hulle insette verwelkom het en aan hulle oorgedra het wat hy van hulle verwag. Daarna is die vertaling deur 'n ander medewerker (die reviseur en proefleser) gereviseer (die eerste 80 bladsye), waarop hy kommentaar gelewer het.

Die reviseur se kommentaar dui daarop dat hy die bronteksouteur en vertaler se insette goed ag, wat daarvan getuig dat hulle samewerking geslaagd was:

I found the translation very, very close to the original Afrikaans. The emotional sense of both versions is as close as they can ever be. I read bits of the English and then bits of the Afrikaans and I really think that the translation is spot-on. Often with a translation into English I itch to jump in and do it differently because I feel the emotional tone is weaker or the atmosphere - the verbal texture is - different, but not in this case. [...]. With some of those books I can clearly see where I'd like to meddle with things to change the sense, but not with Cronje. The tone is measured, sober, understated, with touches of mystery and otherworldliness. 
Daarna lewer hy kommentaar op die aspekte wat aangeraak is in die vertaler en bronteksouteur se notas, wat van interaksie tussen hom en die bronteksouteur (en vertaler) getuig.

Die teks is daarna geredigeer en voorstelle vir verbetering is gemaak. Die proses het deurgaans gepaard gegaan met die uitruiling van veral e-posse, asook notas/memo's. Die redigeerder het 'n uitgebreide lys aanbevelings en navrae per die uitgewer aan die bronteksouteur en vertaler gestuur en opgemerk:

The following comments are things that struck me as I went through [the translation]. I know a lot of them will sound pedantic and nitpicking - but then, as I understand it, it is my job to nipick [sic]. But please regard some of the following as suggestions and ideas rather than imperatives (eie beklemtoning).

Hierdie opmerking getuig daarvan dat die redigeerder haar verantwoordelikheid as teksversorger nagekom het; dus lojaliteit teenoor die doelteks en doeltekslesers getoon het, maar ook respek aan die ander produksieagente bewys het, deur aan te dui dat sy aanpasbaar is ten opsigte van haar aanbevelings en dat sy ander produksieagente se insette verwelkom.

Die vertaler het nadat sy die redigeerder se kommentaar by die uitgewer ontvang het, 'n e-pos aan die bronteksouteur gerig waarin sy haar mening oor die redigeerder se kommentaar uitspreek en waarin sy die bronteksouteur betrek en haar mening oor hoe om voort te gaan, inwin:

[Die uitgewer] het nou vir my die lys queries deurgestuur van die redigeerder. Ek neem aan jy is die een wat die veranderings in die teks inkorporeer. [...] Ek het vinnig deur die lys geskim en daar is duidelik baie voorstelle wat mens net so kan aanneem, maar daar is tog goed waaroor ek nogal sterk voel. [...] Ek het gedink ek sal die lys deurgaan en langsaan kommentaar lewer waar nodig en dit dan vir jou aanstuur. Hoe dink jy? (eie beklemtoning)

Weer eens getuig hierdie korrespondensie daarvan dat die vertaler die bronteksouteur se insette verwelkom en haar hulp as positief beskou (na aanleiding van Jansen 2014).

Die bronteksouteur het bostaande navraag soos volg beantwoord:

Ek het nog nie begin met die deurgaan van die lys nie-maar doen dit gerus: gaan deur en lewer kommentaar waar nodig. Ek sal dit verwelkom (eie beklemtoning).

In hierdie korrespondensie kan die hoë mate van wederkerige vertroue en respek tussen die bronteksouteur en die vertaler opgemerk word en gesien word dat die bronteksouteur ook agting het vir die vertaler en haar insette verwelkom, soos Letawe (2014) ook in haar studie opmerk oor Grass.

Die produksieproses is afgesluit deurdat die teks reg aan die einde geproeflees is deur die reviseur (Potgieter 2011b).

Nadat die konsepvertaling deur die vertaler voltooi is, het die bronteksouteur die hele teks gereviseer deur sekere dele te herskryf/hervertaal (tot 'n beperkte mate) en sekere dele by te skryf. Deur die loop van die proses is sy ook betrek om insette op ander produksieagente se 
insette te lewer en vrae te beantwoord. Sy is deurgaans in alle belangrike besluite wat geneem is, geken en het byvoorbeeld self die titel vir die Engelse doelteks geskep (Potgieter 2011b).

\subsubsection{Bronteksouteur se insette}

By To hell with Cronjé se produksieproses is daar min voorbeelde van veranderinge wat deur die bronteksouteur aangebring is of voorstelle wat deur haar gemaak is, wat nie in die doelteks verskyn nie. Haar bydrae is dus deurgaans, soos in die vorige afdeling bespreek, hoog geag deur die ander produksieagente.

Sy het tydens haar revisie veral veranderinge ten opsigte van oordrag, inhoud en styl (vergelyk Mossop 2007) aangebring en nie juis aandag aan strukturele en taalkundige aspekte geskenk nie.

Wat inhoud en oordrag betref, het die bronteksouteur 'n hele paar veranderinge aangebring of voorstelle vir verandering gemaak, wat meestal deur die ander produksieagente goedgekeur is en in die doelteks verskyn.

'n Voorbeeld van 'n vertaalkeuse wat sy verander het, is die vertaling van die woord "halfbedremmeld" (Winterbach 2007a:136), wat Seun, 'n gestremde karakter, se toestand beskryf terwyl 'n foto geneem word. Sy het dit verander na "looking sheepish" nadat dit deur die vertaler as "looking bewildered" vertaal is, waarskynlik om dit nader aan die betekenis van die woord in die bronteks te bring:

BT: Langs hom staan Seun halfbedremmeld - nie seker wat presies aan die gebeur is nie (Winterbach 2007a:136).

MS1: At his side stands Seun, looking bewildered - not sure what is taking place.

MS2, 3 \& DT: At his side stands Seun, looking sheepish - not sure what is taking place (Winterbach 2007b:160).

Die bronteks se bewoording speel dus hier'n rol in die bronteksouteur se besluitneming.

Op sekere plekke was daar ook semantiese foute, wat as vertaalfoute, onvanpaste vertaalkeuses, of verkeerde interpretasie bestempel kan word, wat sy verbeter het.

Die volgende is ' $\mathrm{n}$ voorbeeld van waar die bronteksouteur ' $\mathrm{n}$ vertaalkeuse tydens haar revisieproses aangepas het:

BT: "Noudat ons in die omgewing van mense is," sê Reitz, "is ek skielik op my senuwees" (Winterbach 2007a:33).

MS1: "Now that we're among people," Reitz says, "I'm suddenly nervous."

MS2, 3 \& DT: "Now that we're in the vicinity of people," Reitz says, "I'm suddenly nervous" (Winterbach 2007b:37).

In hierdie stadium van die roman het die mans pas by 'n verlate plaashuis aangekom. Reitz se opmerking dui aan dat hulle nou 'n omgewing betree waar daar die weerklank of herinnering 
van mense is (in teenstelling met die veld waardeur hulle nou al dae lank reis). Hy sê egter nie dat hulle nou tussen mense is, soos MS2 met die woordkeuse "among" impliseer nie. Die bronteksouteur het dit verander deur eerder van die uitdrukking "in the vicinity" gebruik te maak, waarskynlik aangesien dit nader aan die betekenis van die bronteks is en sy die teks akkurater wou vertaal.

'n Voorbeeld waar die bronteksouteur se verandering nie in die doelteks gebruik is nie, is haar revisie van die beskrywing van hoe Kosie Rijpma die kluts kwyt geraak het. Die vertaler vertaal:

BT: Sy gat in die kamp saam met die vrouens gesien (Winterbach 2007a:39).

as:

MS1: The women in the camp were his undoing.

Hierdie uitdrukking wyk van die betekenis van die oorspronklike af, aangesien dit nou klink of die vrouens sy ondergang beteken het en die geval eintlik was dat hy én die vrouens saam swaargekry het. Die bronteksouteur verander dit gevolglik na:

MS2: He came to a bad end, like most of the women there.

Alhoewel die betekenis nou nader aan die bronteks is, is die uitdrukking "he came to a bad end" nie reg gebruik nie. Die vertaler het hierdie gedeelte in MS3 gemerk en in reaksie op die bronteksouteur se verandering die volgende in 'n nota geskryf:

P. 28: Ek dink nie 'came to a bad end' is reg hier nie. M.i. beteken dit hy is dood. Dalk liewer iets anders?

Sy het egter nie 'n voorstel gemaak van hoe sy dit sou verander nie en die gedeelte is uiteindelik in die doelteks bloot uitgelaat. Dit korreleer met die strategie wat in die Nederlandse vertalings van Grass se werk gevolg is, soos deur Letawe (2014) bespreek is.

Die bronteksouteur het ook dikwels geëkspliseer. Berman (2000:289) beskryf eksplisering as iets wat "aims to render 'clear' what does not wish to be clear in the original". Onnodige eksplisering verwys dus na oorverheldering of oorverduideliking van iets wat die bronteksouteur of vertaler doelbewus implisiet in die teks gemaak het. Hy noem egter dat eksplisering egter nie altyd onnodige verheldering of verduideliking behels nie, maar dat dit'n positiewe strategie kan wees, sou die vertaler iets wat nie duidelik in die bronteks is nie, maar weggesteek of onderdruk word, in die doelteks wou laat manifesteer (Berman 2000:290).

In die volgende teksgedeelte voeg die bronteksouteur 'n deel by om meer inligting te verskaf oor die karakter waarna 'n paar keer in die teks verwys word, naamlik Bettie Loots:

BT: Reitz dink: Van hierdie man weet hy niks, buiten dat hy'n boekie met Bettie Loots se versies sorgvuldig bewaar (Winterbach 2007a:159).

MS1: Reitz thinks: Of this man I know nothing, except that he treasures a volume of verses written by Bettie Loots. 
MS2, 3 \& DT: Reitz thinks: Of this man I know nothing, except that he treasures some verses written by a young woman called Bettie Loots (Winterbach 2007b:186).

Hierdie stukkie bykomende inligting (onderstreep) kan as ekspliserend (vergelyk Berman 2000) gesien word.

In die twee bostaande voorbeelde gebruik die bronteksouteur haar kreatiewe vryheid, mag en statusposisie (verwys na Bourdieu 2002,1993,1986, se "kapitaal") om weer met haar roman om te gaan en teksgedeeltes by te voeg. Die bronteks beïnvloed dus nie in hierdie gedeelte besluitneming nie, aangesien daar afgewyk word van die inhoud daarvan.

Nog 'n voorbeeld van eksplisering is waar die bronteksouteur in die onderstaande teksgedeelte in MS2 "sister's" by die sin voeg om aan te dui na wie die kohesiemerker (wat as 'n stilistiese en strukturele aspek beskou kan word) "her" (Anna, of die suster) verwys:

BT: Anna en haar suster was tot haar dood onversoen, sê Niggie (Winterbach 2007a:179).

MS1: Anna and her sister were unreconciled right up to her death, Niggie says.

MS2, 3 \& DT: Anna and her sister were unreconciled right up to her sister's death, Niggie says (Winterbach 2007b:209).

Hierdie eksplisering help die doelteksleser om dalk die bostaande sin makliker te verstaan, maar is binne die konteks onnodig, aangesien daar in die vorige paragraaf gesê word: "Their mother, Anna's only sister, died recently after a long illness, Niggie tells them" (Winterbach 2007b:209), en daar net na hierdie teksgedeelte gesê word: "Anna is filled with remorse" (Winterbach 2007b:209). Die leser behoort dus maklik te kan aflei na wie die "her" verwys.

Nog so 'n voorbeeld, wat wel nie onnodig ekspliserend van aard is nie (vergelyk Berman 2000), is die volgende teksgedeelte waar die bronteksouteur "It" na "This place" verander om die verwysing duideliker te maak. Hierdie verandering het verbeterde kohesie (wat, soos genoem, as beide 'n strukturele en stilistiese aspek beskou kan word) tot gevolg het.

BT: Daar is 'n oorvloed van insekte: daar is naaldekokers, sê Ben, motte en skoenlappers, kewers en besies, wespe en watermotte - 'n groot verskeidenheid spesies. Ben is opgewonde. Dit is anders hier as die bar omgewings waardeur hulle die afgelope maande beweeg het (Winterbach 2007a:51).

MS1: There are dragonflies, Ben says, moths and butterflies, beetles and bugs, wasps and caddis flies - a large variety of species. Ben is excited. It is so different from the barren regions through which they have been travelling for the past months.

MS2, 3 \& 4: There are insects in abundance: dragonflies, Ben says, moths and butterflies, beetles and bugs, wasps and caddis flies - a large variety of species. He is excited. This place is so different from the barren regions through which they have been travelling for the past months (Winterbach 2007b:59).

Deur "Ben" na "He" te verander, maak die bronteksouteur die verwysing hierbo ook meer implisiet. 
'n Voorbeeld van nog 'n stylverandering wat die bronteksouteur aangebring het, was om soms verkapte vorme (contractions) wat die vertaler gebruik het, na afsonderlike woorde te verander. Hiermee maak sy die styl van die doelteks meer ouwêrelds en formeler om by die toon van die bronteks, wat in 'n "ouer" Afrikaans geskryf is, aan te sluit. Sy verduidelik nie haar rede vir hierdie verandering nie, maar'n mens kan aflei dat haar persoonlike voorkeur, wat deel vorm van haar habitus (verwysend na Bourdieu 1977), hier 'n rol in haar besluitneming gespeel het en/of die bronteks en die styl daarvan besluitneming gestuur het deur' $n$ invloed op die vertaling uit te oefen. Die bronteksouteur verduidelik hoe haar besluit toegepas moet word in 'n nota:

Abbreviated forms such as can't (for example) should be used in direct and reported speech, and the unabbreviated form such as cannot in straight text. It is possible that there are still some inconsistencies in the text, although I have checked.

Hieruit kan 'n mens sien dat die bronteksouteur in haar magsposisie (wat aan haar gesag en outoriteit verleen; vergelyk Bourdieu 1986) as skrywer hierdie stylbesluit as 'n stylreël vir die vertaling vestig (wat onder kopieredigering ressorteer, Mossop 2007).

'n Voorbeeld van waar sodanige verkapte vorm deur die bronteksouteur vervang is, is die volgende:

BT: Hy nooi hulle binne, sodra die perde versorg is (Winterbach 2007a:7).

MS1: He invites them to come into the house once they've seen to their horses.

MS2: He invites [sic] into the house, once they have seen to their horses.

MS3 \& DT: He invites them into the house, once they have seen to their horses (Winterbach 2007b:7).

Die reviseur het die volgende kommentaar hieroor gelewer:

Cannot and can't. I didn't really notice these - but I would agree that the contraction should be kept for direct speech. I can check for inconsistencies at proofing stage.

En die redigeerder gaan akkoord:

I didn't notice the contractions or otherwise, so I think leave them the way they are.

Die bronteksouteur se stylbesluit word dus deur die ander produksieagente goedgekeur/aanvaar en, soos in die geval van die redigeerder, reageer die reviseur en redigeerder positief op die instruksies van die bronteksouteur (verwysend na Jansen 2014). ${ }^{7}$

'n Belangrike stylverandering wat die bronteksouteur tydens haar revisieproses aangebring het, en wat heelwat korrespondensie en onderhandeling (vergelyk Tarutz 1992) tot gevolg gehad het, was waar sy die vertaler se afwisselende vertaling om die "hy sê"-/"sy sê"-patroon te

\footnotetext{
${ }^{7}$ Inkonsekwentheid het wel plek-plek ingesluip en "he'll" ("He'll show them the grave the next morning - if they care to see it." [Winterbach 2007b:7]) en "won't" ("Willem won't hear of it." [Winterbach 2007b:9]) is steeds in verkapte vorm in die doelteks, alhoewel dit nie in hierdie gevalle deel van die direkte rede, dialoog, of indirekte rede is nie.
} 
verbreek, terug verander het na die "hy sê"-/“sy sê"-patroon. Die bronteksouteur het hieroor opgemerk:

In the Afrikaans text I use hy sê virtually with no variation. Ihave [sic] often changed words like he declares, remarks, muses, etc back to he says, as this is characteristic of my style. But it's a difficult one. Please advise (eie beklemtoning).

Die bronteksouteur illustreer hierdeur dat sy graag haar unieke styl wat in die bronteks is in die doelteks wil behou, maar dat sy die ander produksieagente se raad sal waardeer ten opsigte van die oordrag van hierdie dele in die doelteks. Sy illustreer ook hierdeur dat sy dit as haar verantwoordelikheid beskou het om haar unieke styl in die doelteks oor te dra. Dit was dus 'n oorweging ten opsigte van getrouheid aan haarself as skrywer en die bronteks. Die inset het ook 'n interpersoonlike implikasie teenoor die ander produksieagente tot gevolg gehad deurdat die bronteksouteur genoem het dat sy advies sal waardeer. Sy het dus haar vertroue in die ander produksieagente gestel om raad te gee, alhoewel sy noem dat sy die konsepvertaling dikwels na goeddunke aangepas het.

Die reviseur het soos volg op die nota hierbo geantwoord:

At first I thought I would agree that you should keep "he said" throughout. I am in favour of the simple style. But actually I think the way the translator has done it works quite well. The variations are not intrusive - they do soften or round out the texture a bit, but perhaps this is a good thing. One bit I like particularly is on 37 of the translation beginning "Ezekiel was raised by hand," Gert Smal declares suddenly. That whole section - with the words declares, comments, confirms - flows very smoothly and gives a nice feeling of irony.

Die reviseur het hier dus aangedui dat hy ten gunste is van die brontekspatroon, maar dat hy wel dink dat die vertaler se weergawe goed werk en die teks meer vloeiend maak. Vloeiendheid ('n stilistiese aspek, Mossop 2007) was dus vir hom 'n oorweging om die vertaler se weergawe te behou, eerder as die bronteksouteur se afgemete styl. Hy het dus prospektief gedink, met ander woorde na hoe die doelteks aan die doelteksleser oorgedra moet word, eerder as retrospektief waar die bronteks se styl en bewoording noodwendig presies nagevolg sou hoef te word. Sy oorweging het dus daarop berus om die teks vir die doeltekslesers pas te maak.

Gevolglik is die "hy sê"-patroon op sommige plekke behou en op ander, soos in die teksgedeelte waarna die reviseur hierbo verwys, is die vertaler se weergawe in die doelteks gebruik. Dit dui op goeie samewerking tussen die produksieagente om die doelteks te bewerkstellig. ' $\mathrm{n}$ Voorbeeld waar die vertaler se alternatiewe vir die "hy sê"-/“sy sê"-patroon gebruik is, is die volgende:

BT: "Esegiël is hans grootgemaak," sê Gert Smal skielik, "hy het nooit sy eie mense geken nie." / "Arme Kaffer," sê Willem. / "Esegiël ken ons geskiedenis," sê Gert Smal, "oor die geskiedenis en die Bybel kan jy hom nie vasvra nie. / "Arme Kaffer," sê Ben sag. / "Die enigste ding wat jy hom nie kan leer nie," sê Gert Smal, "is om 'n grap te verstaan. [...]" (Winterbach 2007a:48,49).

DT: "Ezekiel was reared by hand," Gert Smal declares suddenly. "He never knew his own people." / "Poor Kaffir," Willem comments. / "Ezekiel knows our history," Gert Smal says,

\footnotetext{
${ }^{8}$ Die raspejoratief is in die dialoog in die tekste gebruik om getrou te wees aan hoe die mense in die tyd waarin die roman afspeel, gepraat het.
} 
"There's nothing you can't ask him about the history and the Bible." / "Poor Kaffir," Ben confirms softly. / "The only thing you can't teach him," Gert Smal continues, "is to catch a joke. [...]" (Winterbach 2007b:56).

'n Voorbeeld waar die "hy sê"-patroon deur die bronteksouteur teruggeplaas is en dit so in die doelteks voorkom, is die volgende:

BT: [...] Willem wys dit ferm van die hand. Hulle slaap so lank reeds nie meer op katels nie, sê hy (Winterbach 2007a:8).

MS1: Willem won't hear of it. It has been so long since they slept in a bed anyway, he protests.

MS2, 3 \& DT: Willem won't hear of it. It has been so long since they slept in a bed anyway, he says (Winterbach 2007b:9).

Bogenoemde is dus 'n voorbeeld van 'n kwessie waaroor daar deur die loop van die produksieproses tussen produksieagente onderhandel (Tarutz 1992) is en daar uiteindelik deur middel van 'n kompromie 'n oplossing gevind is - deurdat die vertaler én die bronteksouteur se styl/benadering afwisselend gevolg is, waar watter produksieagent se styl ook al die beste in die doelteks werk (die doelteksleser speel dus hier 'n implisiete rol as magsagent). Die produksieagente illustreer in hulle korrespondensie oor die kwessie aanpasbaarheid ten opsigte van hulle eie, intrapersoonlike norme (na aanleiding van Toury 2000), disposisies of idees en uitgangspunte (wat deel vorm van hulle habitus [vergelyk Bourdieu 1977]) oor hoe die teks vertaal moet word.

Hierdie stilistiese veranderinge wat die bronteksouteur aangebring het, het haar stem in die doelteks versterk (verwysend na die vraag wat deur Jansen [2014] gestel word oor die teenwoordigheid van die stem van die outeur in die doelteks). Dit is egter gedoen sonder om die vertaler se stem te ondermyn of besluite te neem en veranderinge aan te bring sonder om met die vertaler daaroor te kommunikeer (vergelyk Mossop 2007).

Die wisselwerking tussen die produksieagente van die produksieproses van To hell with Cronjé dui dus deurgaans op goeie samewerking eerder as wedywering of 'n magstryd (wat byvoorbeeld wel in Bogic [2009] se studie bevind is) en die bronteksouteur se insette tot die produksieproses kan as 'n positiewe en nuttige bydrae beskou word.

\subsection{My name is Vaselinetjie}

\subsubsection{Verloop van die produksieproses}

Die vertaler van Vaselinetjie is veral op grond van die SAVI-vertaaltoekenning wat sy toe kort tevore gewen het, aangestel omdat Vaselinetjie volgens die opdraggewende redakteur so 'n uitdagende teks is om te vertaal (Cooper 2011). Die status (Bourdieu 1986) en bewese vaardigheid van die vertaler en die eienskappe van die bronteks het dus hier 'n rol in die keuse van vertaler gespeel. Die redigeerder is onder andere gekies omdat sy voorheen die opdraggewende redakteur van die Afrikaanse bronteks (Vaselinetjie) was en dus bekend was met sowel die bronteks as die bronteksouteur (Cooper 2011). Die bronteksouteur en die bronteks het dus in hierdie besluit 'n rol gespeel. 
Nadat die konsepvertaling voltooi is, het die bronteksouteur dit reviseer deur dit te herbewerk/herskryf of soos sy daarna verwys, "oor te vertaal" (Von Meck 2011). Die bronteks het dus nie so 'n belangrike rol in die produksieproses van Vaselinetjie gespeel soos in die produksieproses van To hell with Cronjé nie.

'n Belangrike tipe verandering wat die bronteksouteur van Vaselinetjie tydens haar revisie van die konsepvertaling aangebring het, was om die vertaling te verwerk om in 2008, in plaas van die 1990's, soos in die bronteks, af te speel. Hierdie tipe veranderinge kan volgens Mossop (2007) se revisieparameters gekategoriseer word as oordrags- en inhoudelike kwessies en tot 'n mate ook stilistiese aangeleenthede. Hierdie veranderinge is meestal daarop gerig om die vertaling meer lewensgetrou en toegankliker te maak vir die nuwe, moderne doeltekslesers, wat dus indirek as belangrike magsagente in die produksieproses opgetree het.

Die ingrypende veranderinge wat die bronteksouteur aangebring het, het volgens die ander produksieagente (die vertaler en redigeerder, Silke 2011b en Steyn 2011b) en soos 'n mens in die notas en e-poskorrespondensie wat hieronder bespreek word, kan sien, tot konflik (vergelyk Hermans 1997) en onnodige onderhandeling (vergelyk Tarutz 1992) tydens die produksieproses gelei, wat interpersoonlike verhoudings, of wisselwerking, gestrem het. Dit was onder meer as gevolg van die stadium in die produksieproses waarin hierdie veranderinge aangebring is dat die vertaler ontevrede was daaroor. Na aanleiding hiervan, kan dit aanbeveel word dat bywerking van 'n teks moet plaasvind alvorens dit vertaal word sodat die voltooide vertaling nie herskryf hoef te word en die vertaler se skepping te veel verander hoef te word nie. Dit sluit aan by Mossop (2007:155) se advies dat veranderinge deur die reviseerder aan die vertaalde teks tot'n minimum beperk moet word.

Die redigeerder het nie die bronteksouteur se verwerking geredigeer nie, maar met die vertaler se konsepvertaling gewerk en dit wat sy as goed beskou het in die bronteksouteur se verwerking, daarin inkorporeer. Die vertaler se besluitneming en insette het dus hier swaarder geweeg en meer vertroue is deur die redigeerder in haar oordeel geplaas.

Die bronteksouteur het egter nadat die redigering afgehandel is, weer deur die teks gewerk en meeste van die veranderinge wat nie inkorporeer is nie, bygevoeg - selfs ten opsigte van kwessies waaroor sy aanvanklik saamgestem het met die vertaler en/of redigeerder. Alhoewel daar vroeër gereelde wisselwerking en korrespondensie tussen die produksieagente was, het daar nie meer vanaf MS4 se produksie korrespondensie plaasgevind nie en die meeste van die veranderinge wat op hierdie stadium deur die bronteksouteur aangebring is, het in die doelteks verskyn. Die opdraggewende redakteur het hier dus aan haar meer outoriteit toegeken as aan die ander produksieagente en 'n magswanbalans en wedywering om mag is duidelik hier te bespeur (soos Bogic [2009] ook in haar studie opgemerk het). Die feit dat daar wel aspekte is wat nie weer deur die bronteksouteur teruggeplaas is of verander is nie, kan daarop dui dat die bronteksouteur in daardie gevalle wel die redigeerder en/of vertaler se mening vertrou en respekteer het. Dit blyk egter meestal nie die geval te gewees het nie.

\subsubsection{Bronteksouteur se insette}

Die bronteksouteur van My name is Vaselinetjie het deur die loop van die produksieproses hoofsaaklik aandag gegee aan kwessies rakende oordrag en inhoud, maar ook veranderinge 
aangebring en aanbevelings gemaak ten opsigte van taalgebruik en styl (verwys na Mossop 2007 se revisieparameters).

'n Voorbeeld van bywerking van die inhoud wat deur die bronteksouteur aangebring is, is die wyse waarop die bendekultuur geïllustreer word. Sy noem ook in 'n nota dat sy verwysings na aspekte soos meer gevorderde tegnologie en dwelms bygevoeg het. Voorbeelde van tegnologie is selfone (wat die kinders self besit - een van die koshuismoeders het wel een in die bronteks) en 'n verwysing na die sosiale netwerk, Mxit. Die bronteksouteur noem verder dat sy die gebruik/misbruik van bier en sigarette aanpas het na die gebruik/misbruik van dagga, tik en "crack"-kokaïene. Hierdie aspekte is deur die bronteksouteur aangepas om moderner en dus geloofwaardiger vir die hedendaagse doelteksleser te wees. In die volgende teksgedeelte word Athlone vervang met Manenberg ('n subarea van Athlone), 'n area wat berug is vir sy bendekultuur en misdaad en dus die oordrag van die bendekultuur by die doelteksleser versterk. Die verwysing na die Liesbeeckrivier word heeltemal uitgelaat. Die bende verkoop ook nie meer slegs "crack" nie, maar die bendekultuur word "donkerder ingekleur" (soos die bronteksouteur na die verandering verwys) deurdat daar nou "tik and mandrax and rocks" gesmokkel word. Tik veral is 'n moderner dwelm wat in die townships en op die Kaapse Vlakte gewild is. In die doelteks word die teksgedeelte verder aangepas deurdat daar gesê word dat hierdie dwelms vir die Nigeriërs gesmokkel word - 'n tendens wat ook oor die afgelope dekade toegeneem het.

BT: Maar soos hy ouer geword het, het hy tog maar elke vakansie in Athlone met sy broer en dié se gompelle rondgehang. Saam met hulle leer baklei, inbrake gedoen en al met die Liesbeeckrivier se kanaal langs crack gesmokkel. Dit was eers aan die einde van graad 8, toe sy beste tjommie in die Bad News Boyz doodgeskiet is, dat hy besluit het om te split (Von Meck 2009b:156).

MS1: Yet, as he grew older, he spent every holiday hanging around in Athlone with his brother and his scaly pals. He joined in their fights, broke into houses and smuggled crack beside the Liesbeeck canal. It was only at the end of grade 8, when his best buddy in the Bad News Boyz was gunned down, that he decided to split.

MS2: Yet, as he grew older, he spent every holiday hanging around in Mannenberg with his brother and his scaly tjoms. He joined in their fights, broke into houses and smuggled tik and mandrax and rocks. It was only at the end of grade 8, when his best buddy in the Bad News Boyz was stabbed to death by a rival gang $[\mathrm{sic}]$, that he decided to split.

MS3 \& 4 \& 5: Yet, as he grew older, he spent every holiday hanging around in Manenberg with his brother and his scaly pals. He joined in their fights, broke into houses and smuggled tik and Mandrax and rocks. It was only at the end of grade 8, when his best buddy in the Bad News Boyz was stabbed to death by a rival gang, that he decided to split.

DT: Yet, as he grew older, he spent every holiday hanging around in Manenberg with his brother and his scaly pals. He joined in their fights, broke into houses and smuggled tik and Mandrax and rocks for the Nigerians. It was only at the end of grade 8 , when his best buddy in the Bad News Boyz was stabbed to death by a rival gang, that he decided to split (Von Meck 2009a:152).

Daar het geen korrespondensie oor hierdie spesifieke veranderinge plaasgevind nie en dit kan impliseer dat die ander produksieagente hierdie veranderinge goedgekeur het.

Op die bronteksouteur se nuwe weergawe van die vertaling (MS2), het die redigeerder onder andere die volgende kommentaar gelewer wat aan die opdraggewende redakteur gestuur is: 
By tye gaan [die bronteksouteur] heeltemal "over the top", sodat dit eintlik dreig om laf of ' $n$ bietjie lagwekkend te word.

Die sosiologiese implikasie van hierdie opmerking was dat dit baie wisselwerking en onderhandeling (vergelyk Tarutz 1992) tot gevolg gehad het, asook konflik (verwys na Hermans 1997) en wantroue tussen die redigeerder en die bronteksouteur tot gevolg gehad het, soos hieronder geïllustreer word.

Die bronteksouteur het op die bostaande opmerking gereageer dat sy die vertaling juis lagwekkend wil maak omdat dit tot die doelteksleser sal spreek. Sy het ook genoem dat sy navorsing gedoen het om te toets of hierdie teksgedeeltes werk, deur van haar sosiale kapitaal (Bourdieu 1986), naamlik kinders wat sy ken, gebruik te maak:

Uh..ja [sic], dis eintlik die idée..om [sic] lagwekkend te wees. Ek bieg onmiddellik dat dit beslis waar is. Daar is TWEE aanpassings in my benadering wat OPSETLIK effe anders as die Afrikaanse weergawe is. Party plekke het dit geflop en verkeerd oorgekom, dankie [...] $\odot$ en ek het aanvaar dat dit moet uit, maar een of twee keer het ek teruggesit wat uitgehaal is. (Dit mag dalk nie vir julle snaaks wees nie, maar dit werk my [sic] kinders. Ek weet, want ek het dit getoets en sal my stelling staaf.) (eie beklemtoning)

Die bronteksouteur noem hierbo dat die redigeerder op sekere plekke reg was dat die nuut bygeskryfde gedeeltes ongeslaagd is (sy bedank haar hiervoor), maar dat ander wel na aanleiding van haar navorsing (deur potensiële doeltekslesers te raadpleeg, soos hierbo aangehaal) in die doelteks geslaagd sal wees. Sy sê ook verder in 'n nota dat kinders "vandag" in 'n onrealistiese "oordrewenheid" leef en ook so praat en sy "is baie ingesteld [daarop] om 'n egte beeld van ons kinders weer te gee". Sy het dus haar aanpassings verduidelik en motiveer (soos Mossop [2007] aanbeveel) deur te noem dat die doelteksleser anders is as die bronteksleser van die tyd waarin Vaselinetjie gepubliseer is. Sy sê kinders vandag is baie meer (1) blootgestel en het volgens haar (2) vervlak. Die karakters in die boek moes ook volgens haar aangepas word, aangesien kinders, veral dié wat minder gegoed is, nie meer in 2008 is soos in die laat jare negentig nie. Sy het daarom ook die intensiteit en kruheid van die tonele "n oktaaf hoër" geneem en 'n paar " "hoërskool' lawwighede en oordrewe beskrywings" bygevoeg (Von Meck 2011).

Die bronteksouteur het wat inhoud (Mossop 2007) betref ook lang gedeeltes bygeskryf, waarop die redigeerder die volgende kritiek gelewer het:

Op party plekke het [die bronteksouteur] aan die skryf gegaan en soveel bygeskryf dat daar nou 'n hele "boggel" in die storie is. Dit word skielik op daardie plek'n heeltemal ander soort storie, wat op 'n ander manier werk as die res. Ek het in sulke gevalle bietjie teruggesnoei.

Die bronteksouteur het geantwoord dat sy na die deurwerk van MS3 die probleme in MS2 duidelik raakgesien het (sy het dus die redigeerder se kommentaar en veranderinge wel in ag geneem), maar het op sekere van haar veranderinge gewys wat wel behoue moes bly in die doelteks. Sy het hierdeur haar magsposisie in die produksieproses versterk, deur byvoorbeeld in 'n nota op te merk: "Ek het van die 'besnoeiing' aanvaar, maar wat ek teruggesit het, WIL EK Hê MOET DAAR BLY. Die inbring van dwelms en gepaardgaande lingo beskou ek dus as non-negotiable, maar as die tempo steeds uit is, verwelkom ek verdere hulp" (eie beklemtoning). Hierdie korrespondensie wys op onderhandeling en wisselwerking tussen die 
bronteksouteur en die redigeerder. 'n Leemte in hierdie wisselwerking kon wees dat die vertaler as skepper van die vertaling nie ook by die onderhandeling betrek is nie.

'n Voorbeeld van 'n gedeelte dialoog wat deur die bronteksouteur bygeskryf is, is waar een van die kinderhuiskinders, Puck, haar aan Vaselinetjie voorstel en haar vertel hoe sy voorheen Ritalin gebruik het. Hierdie opmerking help om die karakter te skets en is ook baie humoristies. Dit werk so effektief, dat die dialoog in die verhoogproduksie van Vaselinetjie (in Afrikaans) (Von Meck en Taaljaard 2012) gebruik word.

BT: Puck praat volstoom sonder om tussen haar sinne asem te haal, maar so sag dat Vaselinetjie moet konsentreer om te hoor (Von Meck 2009b:55).

MS1: Puck was talking nineteen to the dozen, without stopping to breathe between sentences. Her voice was so soft that Vaseline struggled to hear.

MS2: Puck was talking nineteen to a dozen without stopping to breathe between sentences. "I use to be on Ritilin [sic], but the matrons complained I talked too hectic, which was'nt [sic] like true of course," Puck added, as if reading Vaseline's thoughts. Her voice was so soft, though, that Vaseline struggled to make out everything she said.

MS3, 4, 5: Puck was talking nineteen to the dozen, without stopping to breathe between sentences. "I used to be on Ritalin, but the matrons complained I talked too hectic, which wasn't like true of course," she added, as if reading Vaseline's thoughts. Her voice was so soft, though, that Vaseline struggled to hear.

DT: Puck was talking like a lab rat on tik, without stopping to breathe between sentences. "I used to be on Ritalin, but the matrons complained I talked too hectic, which wasn't like true of course," she added, as if reading Vaseline's thoughts. Her voice was so soft, though, that Vaseline struggled to hear (Von Meck 2009a:49).

Die bronteksouteur het die idiomatiese uitdrukking "nineteen to the dozen" eers verkeerdelik verander na "nineteen to a dozen", wat deur die redigeerder gekorrigeer word en later verander word deur die bronteksouteur na "like a lab rat on tik", waarskynlik om by die bywerking ten opsigte van dwelmverwysings aan te sluit.

Soos in die geval van To hell with Cronjé was nog 'n tipe verandering wat die bronteksouteur gereeld aangebring het, om te ekspliseer (vergelyk Berman 2000). Die redigeerder het hieroor opgemerk:

Soms is iets reeds baie pragtig gesuggereer, en dan wil sy dit nog duideliker maak, en dan voeg sy iets by om dit uit te spel, en dan bederf sy daarmee alles.

Hierdie gedeeltes is nie in MS3 geïnkorporeer nie. So ook nie die gedeeltes waar onnodige herhaling volgens die redigeerder voorgekom het nie. Die redigeerder het hiervan melding gemaak in haar redigeer-/revisienota, soos hierbo aangehaal, waarvoor die bronteksouteur haar in 'n nota bedank en dus haar waardering en respek teenoor die redigeerder toon. 'n Voorbeeld van sodanige verandering, waar die bronteksouteur' $n$ teksgedeelte herskryf het om iets beter te verduidelik, is die volgende:

BT: Vaseline kry 'n knop in haar keel. As die tawwe ou Denise eers so smeek, is daar nie meer hoop nie. Denise is een van die kinders wat al van nappy-tyd af hier opgesluit is (Von Meck 2009b:75). 
MS1: Vaseline got a lump in her throat. If tough old Denise was pleading like that, there wasn't much hope for the rest of them. Denise was one of the kids who had been locked up there ever since they were in nappies.

MS2: Vaseline got a lump in her throat. If a tough cookie like Denise was heartbroken like that, there wasn't much hope for the rest of them. Denise was one of the kids who had been locked up at the childrens' [sic] home every since [sic] she had arrived as a baby, still wearing nappies.

MS3, 4, 5 \& DT: Vaseline got a lump in her throat. If a tough cookie like Denise was heartbroken like that, there wasn't much hope for the rest of them. Denise was one of the kids who had been locked up at the children's home ever since she arrived as a baby, still wearing nappies (Von Meck 2009a:70-71). ${ }^{9}$

Die herformulering van die eerste onderstreepte gedeelte in MS2 is 'n herskrywing van MS1 en minder getrou aan die bronteks. Die tweede onderstreepte gedeelte is onnodig ekspliserend, aangesien dit nie nodig is dat daar genoem word dat Denise 'n babatjie was én dat sy steeds in doeke was toe sy by die kinderhuis aangekom het nie. Dit word veronderstel dat die een die ander impliseer - in die bronteks en in die konsepvertaling (MS1). Die frase "at the children's home" is ook onnodig ekspliserend aangesien "there" (MS1) duidelik genoeg na die kinderhuis verwys.

Ander veranderinge wat die bronteksouteur aangebring het en wat 'n invloed op die wisselwerking tussen produksieagente uitgeoefen het, was om byvoorbeeld informeler en kruer taalgebruik in die teks te inkorporeer. Alhoewel die vertaler veral teen laasgenoemde sterk kapsie gemaak het, aangesien sy dit as té kru vir die potensiële lesersgehoor (tienerkinders en moontlik in 'n klaskamersituasie) beskou het, is baie van die kru taalgebruik wel in die doelteks gepubliseer.

Sien byvoorbeeld die volgende kritiek hierop deur die vertaler:

p. 199 - Ek weet van my vloekvertalings was baie kras - daarom het ek staatgemaak op die redigering om dit uit te stryk (ook om in dit in gedagte te hou indien die boek vir skole bedoel is), maar ek kan regtig nie saamgaan met Why don't you go finger yourself nie. Dis heeltemal te vulgêr. Vervang asb met iets anders. Dieselfde geld vir Go wank yourself op p. 69. Ek wil nie voor 'n gemengde klas staan en daardie woorde lees nie. En moet mens weer kyk na cunts op p. 143 ?

Die vertaler het hier dus die doelteksleser en die konteks/situasie in ag geneem waarin die boek moontlik gelees sou kon word, in haar aanbevelings oor die gebruik van kru taal. Haar eie voorkeure (uit haar habitus/disposisies, vergelyk Bourdieu 1977) blyk ook 'n oorweging te wees, omdat sy opmerkings maak soos "ek kan regtig nie saamgaan met" en "Ek wil nie voor 'n gemengde klas staan en daardie woorde lees nie". Dit kan ook aandui dat sy uit 'n verantwoordelikheidsgevoel nie hierdie woorde in die doelteks wou laat verskyn nie.

Albei die uitdrukkings waarna sy verwys het, sowel as die woord "cunt" (op twee plekke) is in die doelteks behou, wat dui op 'n geringskatting van die vertaler se insette of dat die bronteksouteur en/of ander produksieagente bloot nie met die aanbeveling saamgestem het nie.

\footnotetext{
${ }^{9}$ Die redigeerder bring slegs $n$ tikfoutverbetering (every - ever) aan, maar verander nie aan die res van die teksgedeelte nie.
} 
Voorbeeld 1: Puck se ma, 'n prostituut, is in die volgende teksgedeelte aan die woord:

BT: "Piss off, I'm busy!" skel 'n vrouestem binne. Dan klink dit asof die persoon in 'n hoesbui verstik en spoeg (Von Meck 2009b:81).

MS1: "Piss off, I'm busy!" a woman's voice shouted from inside. They heard her coughing and spitting. It sounded as if she was choking.

MS2, 3, 4, 5 \& DT: "Go wank yourself, I'm busy!" a woman's voice shouted from inside. They heard her coughing and spitting. It sounded as if she was choking (Von Meck 2009a:76)

Voorbeeld 2: Killer, 'n kinderhuisbewoner (meisie), is in die volgende teksgedeelte aan die woord:

BT: "Gaan speel eerder met jouself," sê Killer en haak die ruit weer toe (Von Meck 2009b:216).

MS1: "Why don't you go and play with yourself?" Killer said, closing the window.

MS2, 3, 4, 5 \& DT: "Why don't you go finger yourself?" Killer said, closing the window (Von Meck 2009a:217).

Voorbeeld 3: Hier word "cunt" in die doelteks gebruik om die woord "bitches" te vervang:

BT: "Vrek, julle werfetters!" skree sy broodmes in die hand terwyl sy oor die toonbank terug in die aksie in spring (Von Meck 2009b:51).

MS1: “Die, motherfuckers!" she shouted, wielding a bread knife and leaping across the counter and back into the fray.

MS2: “Die, motherfuckers!" she shouted, wielding a bread knife and leaping across the counter and back into the fray.

MS3 \& 4: "Die, you bitches!" she shouted, wielding a bread knife and leaping across the counter and back into the fray.

MS5 \& DT: "Die, you cunts!" she shouted, wielding a bread knife and leaping across the counter and back into the fray (Von Meck 2009a:45).

Die vertaler het, soos vroeër genoem, aanvanklik opgemerk dat haar vertaling van "werfetters" na "motherfuckers" dalk te kras kon wees. Die redigeerder het dit in MS3 verander na "bitches" en in MS5 is dit deur die bronteksouteur na nog 'n meer vulgêre term, "cunts", verander.

Die bronteksouteur het egter ook soms die kru taalgebruik versag wanneer dit nie by die karakter pas nie. Die hoofmeisie, Tara, se woorde: "Fuck off!" (MS1) is vervang met "Piss off!" (MS2 en Von Meck 2009a:65). En die huismoeder, mevrou Claerhout, se woorde: "Goodness, what's gotten into you bitches?" (MS1) is vervang met "Goodness, what's gotten into you hooligans?" (MS2 en Von Meck 2009a:65).

Die bronteksouteur het ook ander veranderinge ten opsigte van taalgebruik aangebring, byvoorbeeld waar sy in die volgende teksvoorbeeld "to learn hard", wat in MS1 gebruik word, na die effe meer idiomatiese Engels, "to study hard", verander het: 
BT: Probeer hard leer en goeie punte kry, probeer stilsit as die onderwysers praat en altyd beleef wees met almal (Von Meck 2009b:68).

MS1: To learn hard and get good marks, to sit quietly while the teachers were talking and to be polite to everyone.

MS2, 3, 4, 5 \& DT: To study hard and get good marks, to sit quietly while the teachers were talking and to be polite to everyone (Von Meck 2099a:62).

Hierdie verandering kan ook as bloot 'n stylverandering van die informeler "learn" na die formeler "study" bestempel word. Die bronteksouteur het nie hierdie besluit motiveer nie, maar 'n mens kan aflei dat dit haar voorkeur (afkomstig uit haar interpersoonlike norme/disposisies/habitus, Bourdieu 1977) is. Die verandering kon ook aangebring geword het met die doelteksleser in gedagte. Sy het byvoorbeeld dikwels in notas opgemerk dat sy nie wil hê dat die doelteks styf en formeel moet wees nie, om by die tema en potensiële doelteksleser te pas. Sy wou dus die vertaling se styl vir die doeltekslesers toeganklik maak en die taalgebruik en register (styl) moes volgens haar so eenvoudig moontlik gehou word.

Die bronteksouteur sê een van die eerste dinge wat haar oor die konsepvertaling (MS1) opgeval het, was die wordkeuse "mat" (Engels) om die Afrikaanse "mat" te vertaal (Von Meck 2011). Dit wil voorkom of hierdie vertaalkeuse die bronteksouteur besonder baie gepla het en haar vertroue in die vertaler se oordeel laat verloor het. Dit kon waarskynlik daartoe gelei het dat sy baie veranderinge in die teks aangebring het omdat sy nie meer vertroue in die vertaler se oordeel gehad het nie. Sy het oor die vertaler gesê: "Ek glo sy het haar bes probeer. Dit is 'n baie moeilik [sic] storie om in egtheid te behou terwyl jy dit letterlik van die Afrikaanse platteland na die Engelse voorstad probeer verhuis" (Von Meck 2011).

Die bronteksouteur het gevolglik "mat" na "carpet" verander. "Carpet" is egter 'n formeler variant as "mat" (wat wel 'n idiomaties korrekte vertaling vir die Afrikaanse "mat" is) en dus teenstrydig met haar gevoel dat die boek in 'n eenvoudiger taal en informeler register vertaal moet word. "Mat" is wel op verskeie ander plekke in MS1 gebruik en deurgaans in MS1 met "carpet" vervang en in die doelteks gebruik:

BT: Maar sy kan nie help om sleg te voel oor die kleintjies wat elke dag vir ure tjoepstil op 'n mat voor die televisie moet sit nie (Von Meck 2009b:110).

MS1: But she couldn't help feeling bad about the little ones who had to sit quietly on the mat in front of the TV for hours on end.

MS2, 3, 4, 5 \& DT: But she couldn't help feeling bad about the little ones who had to sit quietly on the carpet in front of the TV for hours on end (Von Meck 2009a:105).

Nog 'n voorbeeld waar die bronteksouteur in MS2 stilistiese veranderinge aangebring het, is in die volgende teksgedeelte. Sy het "immensely" na die eenvoudiger "a lot" verander, maar stylbreuk gepleeg deur net daarna die formele, ouer frase "something was amiss" te gebruik. Die redigeerder het nie hierdie verandering inkorporeer nie en "immensely" is in MS3 gebruik. Die bronteksouteur het in MS4 "something was amiss" na "something was terribly wrong" verander. In die doelteks word albei die bronteksouteur se formulerings, naamlik "a lot" en "something was terribly wrong" gebruik wat weer eens op haar sterk invloed op die doelteks dui: 
BT: Ná kerk vat Oupa hulle om ietsie soets by die keffie in die bodorp te gaan eet. Dis 'n rare gebeurtenis en Vaselinetjie geniet dit gewoonlik vreeslik, maar vandag voel dit of Ouma en Oupa nie die toringroomyse vol bruin sjokoladesous in hulle glase geniet nie (Von Meck 2009a:12)

MS1: After church Oupa took them to the café in the bodorp for a treat. This was a rare event and usually Vaseline enjoyed it immensely, but today she sensed that Oupa and Ouma were taking no pleasure at all in the tall ice creams dripping with dark brown chocolate sauce in their glass bowls.

MS2: After church Oupa took them to the café in the bodorp for a treat. This was a rare event and usually Vaseline enjoyed it a lot, but today she sensed something was amiss. Oupa and Ouma were taking no pleasure at all in the tall ice creams dripping with dark brown chocolate. sauce in their glass bowls.

MS3: After church Oupa took them to the café in the bodorp for a treat. This was a rare event and usually Vaselinetjie enjoyed it immensely, but today she sensed that something was amiss. Oupa and Ouma were taking no pleasure at all in the tall ice creams dripping with dark brown chocolate sauce in their glass bowls.

MS4, 5 \& DT: After church Oupa took them to the café in the bodorp for a treat. This was a rare event and usually Vaselinetjie enjoyed it a lot, but today she sensed that something was terribly wrong. Oupa and Ouma were taking no pleasure at all in the tall ice creams dripping with dark brown chocolate sauce in their glass bowls (Von Meck 2009a:6).

Die inset van die bronteksouteur het dus hier swaar geweeg en hierdie voorbeeld kan daarop dui dat die bronteksouteur nie die vertaler en redigeerder (wat albei "immensly" voorgestel het) se oordeel of bevoegdheid vertrou het nie en dat sy haar eie oordeel vertrou het (of haar voorkeur, wat deel vorm van haar habitus [Bourdieu 1977]) verkies het en verantwoordelikheid vir die eindproduk wou neem.

Uit die notas en teksvoorbeelde wat hierbo bespreek is, kan 'n mens sien dat die bronteksouteur met tye 'n positiewe bydrae tot die produksieproses van My name is Vaselinetjie gelewer het, maar dat haar betrokkenheid ook dikwels tot wedywering en 'n magswanbalans tussen produksieagente gelei het, wat nie maklik opgelos kon word nie en die produksieproses gestrem het, veroorsaak het dat die ander produksieagente ontevrede was met die verloop van die proses (Silke 2011b en Steyn 2011b) en moontlik ook die doelteks tot 'n mate skade berokken het. Soos genoem, was die probleem in hierdie geval ook moontlik dat die proses self nie logies verloop het nie en die herskrywing en bywerk van die teks eerder moes plaasvind alvorens die teks vertaal is (soos die navorser in haar model vir die verloop van die produksieproses van literêre vertalings aanbeveel, [Spies 2013]).

\subsection{In bushveld and desert: A game ranger's life}

\subsubsection{Verloop van die produksieproses}

Die produksieproses van In bushveld and desert: A game ranger's life het begin by die keur van verhale wat in die bundel moes verskyn. Daarna het die vertaler 'n proefvertaling gedoen. Drie van die verhale in die proefvertaling is deur die uitgewer gelees en gekeur en 'n paar voorstelle is gemaak om dit te verbeter. Die vertaler het daarna die res van die verhale vertaal. Daarna is die konsepvertaling na die samesteller wat verbeteringe, asook strukturele veranderinge ten opsigte van die chronologie/volgorde van die verhale aangebring het. Die 
manuskrip met haar verbeteringe en opmerkings is na die vertaler, wat toe na die veranderinge en voorstelle gekyk en kommentaar daarop gelewer het. Sy het heelwat kapsie gemaak teen die tipe veranderinge wat deur die samesteller aangebring is, veral ten opsigte van eksplisering (vergelyk Berman 2000) en die verandering van die chronologie van verhale (Spies 2013). Net soos by My name is Vaselinetjie moes hierdie uitgebreide veranderinge dalk eerder aangebring geword het voor die vertaling gedoen is. Hierdie probleme word egter nie in hierdie artikel bespreek nie, aangesien dit fokus op die rol van die bronteksouteur. Die bronteksouteur het ook kommentaar gelewer op die vertaalnota waarin kwessies uitgelig is, deur die samesteller se revisie gewerk en daarop kommentaar gelewer, asook plek-plek verbeteringe aangebring. Die manuskrip is daarna deur die redigeerder versorg. Die vertaler het ook die geleentheid gekry om die geredigeerde/gereviseerde weergawe deur te werk en kommentaar daarop te lewer en van haar voorstelle is in die doelteks inkorporeer. Daarna is die vertaling deur die bronteksouteur deurgewerk, geproeflees en gepubliseer.

Soos uit die bostaande uiteensetting van die produksieproses gesien kan word, is die bronteksouteur deurgaans tydens die produksieproses van die doelteks geraadpleeg en die kans gegun om insette te lewer, maar hy het nooit self die teks gereviseer/geredigeer nie. Hy sê hy verkies om nie té nóú betrokke te raak by die produksieproses van die vertaling van sy werk nie. Volgens hom, as hy 'n boek klaar geskryf het, "moet dit sy eie loop neem" (Bakkes 2011). Hy was ook nie betrokke by die kies van vertalers en redigeerders en/of reviseurs vir sy werk nie en sê hy plaas sy volle vertroue in sy uitgewer omdat hy "nie in voeling met die bedryf [is] nie" (Bakkes 2011).

Die bronteksouteur het wel in 'n rol gespeel in die keuse van medewerkers: Die samesteller vir hierdie bundel is genader vanweë haar ervaring as redakteur/redigeerder (ook van Christiaan Bakkes se Afrikaanse boeke) en haar groot waardering vir Bakkes se skryfwerk (Potgieter 2011a). Die redigeerder is onder andere gekies omdat sy al, by verskeie geleenthede, haar waardering vir Bakkes se verhale teenoor die uitgewer laat blyk het (Potgieter 2011a).

\subsubsection{Die bronteksouteur se insette}

Die bronteksouteur het 'n groot rol in die produksieproses van In bushveld and desert: A game ranger's life gespeel om seker te maak die korrekte bedoelde betekenis word oorgedra vanuit die bronteks en dat die vertelling van gebeure reg oorgedra word (verwys na Mossop 2007). Dit sluit aan by die aanbeveling wat in Translation in practice (Paul 2009) gemaak word dat veranderinge wat daarop gerig is om die teks verstaanbaarder te maak, aan die bronteksouteur voorgelê moet word.

Daar was deurgaans, met die uitgewer as tussenganger, wisselwerking tussen die bronteksouteur en die ander produksieagente om aspekte te verklaar of te verhelder of raad te gee oor hoe terme vertaal moet word. Deurgaans is die bronteksouteur deur die ander produksieagente geraadpleeg oor kwessies waaroor hulle onseker was en om sekere aspekte in die bronteks te verklaar, soos daar in die volgende voorbeelde geïllustreer sal word.

Die vertaler het byvoorbeeld die bronteksouteur geraadpleeg rakende die betekenis en vertaling van terminologie: 
Daar is so baie gebiede waarvan ek min of geen kennis het nie en bes moontlik heeltemal die verkeerde woorde gekies het, bv jag, gewere, veldwagters en hul range, die weermag, ens. [die bronteksouteur] moet asb maar fyn kyk en uitwys/verbeter waar nodig.

Die vertaler het byvoorbeeld in 'n nota opgemerk: "Ek weet nie wat 'batterytoetse' is nie. Ek het dit vertaal met 'fitness tests'. Help?" Die bronteksouteur het die vraag beantwoord deur te sê dat "fitness test" of "endurance test" sal werk. Een van die vertaler se voorstelle, naamlik "fitness test" (Bakkes 2008:38) is deur die bronteksouteur goedgekeur en in die doelteks gebruik.

Die bronteksouteur het ook gehelp met die vertaling van dierename. Hy het byvoorbeeld genoem dat dit in die bedryf aanvaarbaar is om "blesbok" in plaas van die Engelse "blesbuck" te gebruik. Die Afrikaanse term, "blesbok" is gevolglik in die doelteks gebruik. Hy het dieselfde verandering by "springbuck" en "gemsbuck" aangebring wat gevolglik "springbok" en "gemsbok" word in die doelteks. Hierdie verandering sluit aan by sy uitgangspunt dat hy die sogenaamde "Afrikanerstem", of "Afrikaanse stem", in die doelteks wou behou (Bakkes 2011); 'n oorweging wat uit die bronteksouteur se habitus (na aanleiding van Bourdieu 1977) spruit en aansluit by die tema, inhoud en outobiografiese inslag van die verhale.

Hierdie aanbevelings van die bronteksouteur is oor terme waarmee hy vertroud is en die ander produksieagente nie noodwendig nie. Hy kon dus uit die kennis wat deel vorm van sy kulturele kapitaal (vergelyk Bourdieu 1986) veranderinge ten opsigte hiervan aanbring. Die bronteksouteur se habitus (vergelyk Bourdieu 1977) en sy kulturele kapitaal in die vorm van kennis en ervaring het dus hier'n invloed op die produksieproses uitgeoefen.

Uit die bostaande voorbeelde, kan 'n mens sien dat alhoewel die bronteksouteur nie uitvoerig aan die teks geredigeer/reviseer het nie, hy wel gehelp het om met vertaalekwivalente vir sekere terme en begrippe vorendag te kom - veral na aanleiding van opmerkings wat die vertaler gemaak het. Hierdeur word geillustreer dat dit nuttig is vir die bronteksouteur, wat 'n kenner is oor die onderwerpe waarna daar in die teks verwys word, om ook betrokke te wees by die produksieproses van 'n literêre vertaling om raad te gee, verduidelikings te verskaf en uit te wys indien vertaalfoute begaan is. Daar is dus deurgaans in hierdie proses, soos daar in Translation in practice (Paul 2009) aanbeveel word, in oorleg met die bronteksouteur gewerk en die bostaande voorbeelde dui daarop dat die vertaler positief op die bronteksouteur se instruksies gereageer het en die bronteksouteur se hulp waardeer het en selfs ingeroep het (verwysend na Jansen 2014).

Die samesteller het heelwat opmerkings in MS2 gemaak om vir die bronteksouteur aan te dui waar hy sekere inligting moes byvoeg om die teks logieser aan te bied vir die doelteksleser. Die rede hiervoor was omdat die logika wat in die brontekste se oorspronklike samestellings bewerkstellig is, nou verlore gegaan het, aangesien slegs sekere verhale uit die onderskeie brontekste nou in 'n nuwe kombinasie en volgorde in die doelteks aangebied is. Die bronteks het dus ' $\mathrm{n}$ al minder beduidende faktor geraak wat besluitneming gerig het en die tekste is tot ' $\mathrm{n}$ mate gemanipuleer (verwysend na Lefevere 1992, Hermans 1985 en Mossop 2007) om dit as 'n nuwe versameling in 'n nuwe chronologie en samestelling vir die doelteksleser aan te bied en op hierdie manier 'n nuwe, selfstandige doelteks te skep. 
By die kortverhaal "Turning point" het die bronteksouteur byvoorbeeld in 'n e-pos aan die uitgewer genoem dat sy "aangedui [het] waar die skrywer moet invul tov mense se identiteit en plek om die storie sinvol te maak". Voorbeelde hiervan is:

\section{Voorbeeld 1:}

MS2: After spending a day at Mwanza on the banks of Lake Victoria in Kenia [skrywer: is dit korrek?] [...].

Die bronteksouteur het hierdie gedeelte gekorrigeer na "in Tanzania". Die sin lui soos volg in die doelteks:

DT: A month later I reached Mwanza on the banks of Lake Victoria in Tanzania (Bakkes 2008:107).

\section{Voorbeeld 2:}

MS2: The next day I returned to the snake park where [skrywer: vul in waar dit is en wanneer jy hier gebly het - noem wie Wade is, ter wille van verwysing wat volg]. Allistair and his friends stayed behind to organise a safari. He promised to call on me at the snake park.

Die verwysing waarna die samesteller hier verwys het, was: "Seated next to her was Wade's girlfriend, Melinda." (Bakkes 2008:108), terwyl Wade in hierdie nuwe saamgestelde doelteks nog nie bekendgestel is aan die doelteksleser nie.

Die bronteksouteur het vervolgens hier ingevoeg: "which I used as a temporary base while traveling through Tanzania. There I have $[$ sic $]$ befriended Wade Bale, $[$ sic $]$ the manager of the Meserani Snake park. His parents runs [sic] the bar and campsite." Die teksgedeelte lui soos volg in die doelteks:

DT: The next day I started walking back to the snake park which I used as a temporary base while travelling through Tanzania.There [sic] I'd befriended Wade Bale, the manager of the Meserani Snake Park. His parents ran the bar and the camp site. Allistair and his friends stayed behind to organise a safari. He promised to call on me at the snake park (Bakkes 2008:108).

Net soos die produksieagente die bronteksouteur in hulle besluitneming geken het, het die bronteksouteur ook deurgaans respek vir en vertroue in die ander produksieagente getoon. Hy het byvoorbeeld in 'n e-pos aan die uitgewer die volgende opgemerk nadat daar vir hom gevra is of hy met die keuse van die nuwe chronologie waarin die verhale deur die samesteller aangebied is, saamstem:

Dankie vir jou moeite. Ek hou van die keuse van verhale. Die chronologie lyk hoofsaaklik reg. Bittereinder is nie heeltemal chronologies korrek nie, dit het vroeer [sic] plaasgevind maar ek dink tog dit sal werk waar dit is. Ozohavera moet voor Toorsafari inkom en Afrikaans must stop moet na Steppenwolf. Ek is tevrede met alles. Sou julle besluit om fotos [sic] te plaas, laat maar weet, ek het albums vol. Tussen jou en [die samesteller] en [die vertaler] glo ek my stories is in goeie hande (eie beklemtoning).

Meeste van die bronteksouteur se kommentaar was in reaksie op die vertaler en samesteller se navrae en aanbevelings, maar hy het wel'n paar opmerkings gemaak en verbeteringe aangebring 
wat onafhanklik van die ander produksieagente se kommentaar was. Hy het deurgaans sy aanbevelings in notas per e-pos aan die uitgewer gestuur en aan die ander produksieagente gemotiveer (soos Mossop [2007], aanbeveel 'n reviseur behoort te doen).

'n Voorbeeld hiervan is waar hy aangedui het dat die woord "aangetas" (Bakkes 2007:51) in die kortverhaal "Brothers" eerder as "infect" en nie "include" nie, vertaal moet word:

BT: Toe die leeus verby is, sê oom Bennie: "Ek hoop nie die epidemie vorder so dat die leeus aangetas word nie" (Bakkes 2007:51).

MS2: "When the lions had passed, Oom Bennie spoke in Afrikaans: 'Ek hoop nie die epidemie vorder so dat die leeus aangetas word nie' - I hope the epidemic doesn't spread to include the lions."

MS3 \& DT: "When the lions had passed, Oom Bennie spoke in Afrikaans: 'Ek hoop nie die epidemie vorder so dat die leeus aangetas word nie' - I hope the epidemic doesn't spread to infect the lions" (Bakkes 2008:84).

Nog 'n voorbeeld in "Brothers" waar die bronteksouteur 'n ander woordkeuse of vertaalekwivalent voorgestel het, is by die volgende teksgedeelte deur "cover" na "mount" te verander:

BT: Saam patrolleer die twee jong leeus die Shisakarangondzo. Hulle beskerm mekaar se rug. Die leeuwyfies langs die rivier word om die beurt deur hulle gedek. Die jong welpe behoort aan óf die een óf die ander. Eendrag makk mag (Bakkes 2007:54).

MS2: [...] They took turns to cover the lionesses along the river bank.

MS3 \& DT: [...] They took turns to mount the lionesses along the river bank (Bakkes 2008:87).

Uit die konteks van die paragraaf - veral die sin oor die jong welpe, kan 'n mens sien dat die "dek" waarna hier verwys word, "paar" beteken. "Cover" werk wel hier, aangesien dit volgens die Collins English Dictionary (CED) beteken "(of a male animal, esp a horse) to copulate with (a female animal)" (CED 2014). Die bronteksouteur het egter die woord "mount" verkies en hierdie woordkeuse word in die doelteks gebruik.

Die bostaande voorbeelde dui almal op woordkeuses/vertaalkeuses wat verander is omdat dit die bronteksouteur se voorkeur is (wat deel van sy norme/disposisies, of habitus vorm [Bourdieu 1977]).

Die bronteksouteur was die laaste persoon wat na die manuskrip gekyk het voor dit geproeflees en gepubliseer is - wat dui op die status (simoliese kapitaal, na aanleiding van Bourdieu 1986) wat hy in die produksieproses geniet het. Sy finale nota aan die produksieagente (wat hy per e-pos aan die uitgewer gestuur het) het enkele opmerkings en aanbevelings bevat.

Hy het byvoorbeeld twee feitefoute gekorrigeer: 'n Datum wat in die kortverhaal "The battle for the mealie fields" wat verkeerd aangedui is as "June 1988" na "June 1998" verander; en verduidelik dat John Toyvo, wat ook in hierdie storie genoem word, 'n Themba is en nie 'n Dhimba nie. Slegs die bronteksouteur kon hierdie veranderinge aanbring aangesien hy die feite van die verhale, wat 'n sterk outobiografiese inslag het, ken. 
Hy het ook byvoorbeeld 'n sin laat verwyder wat volgens hom nie respekvol is nie:

bl 140 Verwyder die sin: The Ovambos don't want to be reminded that their women went about topless less than a hundred years ago. Dis nie respekvol nie.

Die bronteksouteur het hier 'n persoonlike voorkeur uitgeoefen (afkomstig uit sy habitus [Bourdieu 1977]) deur nie hierdie verwysing in die doelteks te inkorporeer nie, alhoewel dit wel in die bronteks verskyn. Die bronteks het dus nie in hierdie voorbeeld 'n beduidende rol in besluitneming gespeel nie. Die oorweging is verder gemotiveer deur die bronteksouteur se respek vir persone wat buite die produksieproses funksioneer, maar oor wie geskryf word.

Daar is nie verder oor hierdie opmerkings onderhandel of gekommunikeer nie en dit is in die doelteks inkorporeer.

Alhoewel die bronteksouteur nie self geredigeer/gereviseer het nie, het hy wel 'n belangrike bydrae gelewer tot die produksie van 'n akkurate en getroue doelteks, is gereeld geraadpleeg tydens die produksieproses en die ander produksieagente het ook dikwels vrae spesifiek aan hom gerig. Hy het ook deurgaans na die teks gekyk en kommentaar en insette daarop gelewer en sy stem (verwysend na Jansen 2014) is deurgaans in die doelteks opmerkbaar - as gevolg van die outobiografiese inslag van sy werk en die insette wat hy in die vertaling en vertaalproses gelewer het. Die voorbeeldtekste getuig ook daarvan dat die bronteksouteur deurgaans sy vertroue in die ander produksieagente gestel het en hulle insette waardeer het. Die produksieproses het wat die wisselwerking tussen die bronteksouteur en die ander produksieagente betref, dus vlot verloop en daar was geen konflik, magswanbalanse of wedywering tussen die bronteksouteur en ander produksieagente nie. Die produksieagente het deurgaans positief gereageer op die bronteksouteur se instruksies en hulp en dit in der waarheid aangemoedig of aangevra (om Jansen, 2014, se vraag hieroor te beantwoord). Benewens die proefleser was die bronteksouteur ook die laaste produksieagent wat die teks onder oë gehad het, wat op sy magsposisie/status in die produksieproses dui.

\subsection{Paratekstuele elemente}

'n Belangrike plek waar die mag en status van die produksieagente, asook die betrokkenheid van elkeen, by die produksieproses opgemerk kan word, is in die parateks (Genette 1997) van 'n vertaling. Dit is hier waar die produksieagente se insette erken word en daar dikwels aangedui word wat hulle bydrae tot die produksieproses was. Die betrokkenheid van die bronteksouteurs in die drie produksieprosesse wat in hierdie artikel ondersoek word en hulle prominensie, of status (simboliese kapitaal, Bourdieu 1986), word duidelik in die parateks van elke doelteks aangedui.

In al drie die boeke wat in hierdie artikel ondersoek word, verskyn slegs die naam van die bronteksouteur op die buiteblad/omslag van die doelteks. Die vertaler word telkens op die titelbladsy en op die kolofonbladsy erken, wat haar betrokkenheid sigbaar maak (vergelyk Venuti [1995], se opmerking oor die (on)sigbaarheid van die vertaler). Op To hell with Cronjé se titelbladsy word die produksieagente aangedui as:

Translated by Elsa Silke

in collaboration with the author 
Aangesien die bronteksouteur self so nóú betrokke was by die vertaalproses en besluitneming en self aan die vertaling gereviseer/geredigeer het, word haar naam ook hier genoem. Sy het boonop later saam met die vertaler in aanmerking gekom vir die SAVI-vertaalprys waarvoor hierdie roman genomineer is. Die gedeelte "in collaboration with the author" is wel kleiner gedruk om die vertaler se naam te beklemtoon, aangesien die bronteksouteur se naam reeds prominent op die buiteblad/omslag verskyn (Potgieter 2011b).

Die vertaler sê sy sien dit as 'n goeie uitweg om hierdie wisselwerking aan te dui, aangesien baie van die vertaalbesluite ook deur die bronteksouteur self geneem is en hulle baie nóu saamgewerk het (Silke 2011b).

Op My name is Vaselinetjie se titelbladsy word die bronteksouteur ook as medewerker aangedui aangesien sy baie werk aan die vertaalde teks verrig het. Dit lui soos volg:

\section{Translated from the Afrikaans by Elsa Silke \\ Updated and revised by the author}

Omdat daar nie werklik samewerking tussen die vertaler en die bronteksouteur in hierdie geval was nie, maar die bronteksouteur wel ingrypende veranderinge in die vertaling aangebring het en dele bygeskryf en hersien/bygewerk het, is die woorde "updated and revised" gekies. Weer eens, is die erkenning aan die bronteksouteur kleiner gedruk om die vertaler se naam te beklemtoon, aangesien die bronteksouteur se naam reeds op die buiteblad/omslag verskyn.

Hierdie parateks dui op die oorleg wat daar tussen die vertaler en die bronteksouteur gepleeg is, waarna Paul (2009) en Mossop (2007) verwys.

By In bushveld and desert: A game ranger's life word die bronteksouteur se naam nie ook saam met die vertaler s'n op die titelbladsy aangedui nie, aangesien hy nie so intensief betrokke was by die produksieproses nie en nie redigeer/revisiewerk aan die teks verrig het nie. Sy naam word wel op die buiteblad/omslag van die doelteks aangedui.

Ander maniere waarop die bronteksouteurs se prominensie beklemtoon word, is deur die bioskets van die bronteksouteur in My name is Vaselinetjie en In bushveld and desert: A game ranger's life, die verwysings na pryse wat die skrywers vir die brontekste gewen het in To hell with Cronjé en My name is Vaselinetjie, die foto's van die bronteksouteur op die agterblaaie van To hell with Cronjé en In bushveld and desert: A game ranger's life én die foto's van die bronteksouteur op die voorblad en in die fotoseksie van In bushveld and desert: A game ranger's life. In hierdie doelteks is die hoofkarakter se naam ook dié van die bronteksouteur, Chris ('n afkorting vir Christiaan), waar dit in die bronteks "Stoffel Matthysen", 'n pseudoniem afkomstig van sy doopname, Christiaan Mathys, is. Dit was'n doelbewuste keuse (soos die eposkorrespondensie oor hierdie kwessie tussen die produksieagente getuig [Spies 2013]) wat deur die samesteller voorgestel is en deur die uitgewer en bronteksouteur goedgekeur is.

Deurgaans is die "ekstratekstuele stem" van die bronteksouteur, waarna Jansen (2014) verwys, dus sigbaar in die parateks van die doeltekste en die doelteksleser is deeglik bewus van wie die bronteksouteur van die onderskeie tekste is. 


\section{Gevolgtrekking}

Die bronteksouteurs van die drie brontekste wat in hierdie artikel bestudeer word, is telkens deur die uitgewer/opdraggewende redakteur by die produksieproses betrek en tot 'n groot mate vryheid gegun om so betrokke by die produksieproses te wees soos wat hulle wou. Al drie die bronteksouteurs is genader om ander produksieagente se navrae te beantwoord en notas en vrae is dikwels aan hulle gerig. Twee van die bronteksouteurs het ook redigeerwerk/revisiewerk en selfs op sekere plekke vertaalwerk aan die manuskripte verrig. Tabel 2 dui die werk aan wat deur die bronteksouteurs in die drie produksieprosesse verrig is:

Tabel 2: Werk wat deur die bronteksouteurs in die produksieprosesse verrig is

\begin{tabular}{|c|c|c|c|c|}
\hline & 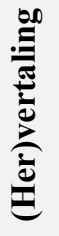 & 竞: & 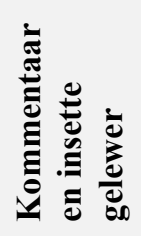 & 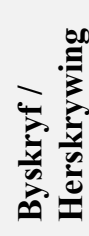 \\
\hline $\begin{array}{l}\text { To hell with } \\
\text { Cronjé }\end{array}$ & $\checkmark$ & $\checkmark$ & $\checkmark$ & $\checkmark$ \\
\hline $\begin{array}{l}\text { My name is } \\
\text { Vaselinetjie }\end{array}$ & $\checkmark$ & $\checkmark$ & $\checkmark$ & $\checkmark$ \\
\hline $\begin{array}{l}\text { In bushveld } \\
\text { and desert: } \\
\text { A game } \\
\text { ranger's life }\end{array}$ & & & $\checkmark$ & $\checkmark$ \\
\hline
\end{tabular}

By To hell with Cronjé en My name is Vaselinetjie kan die werk wat hoofsaaklik deur die bronteksouteurs verrig is, as revisie bestempel word. Verder het die bronteksouteur van To hell with Cronjé plek-plek help vertaal en plek-plek gedeeltes herskryf. By My name is Vaselinetjie het die bronteksouteur ruimskoots die teks hervertaal, verwerk/bygewerk en teksgedeeltes bygeskryf (soos die teksvoorbeelde aandui en sy self beaam [Von Meck 2011]). Albei dié bronteksouteurs het ook kommentaar gelewer oor die insette van die ander produksieagente deur middel van e-posse en notas. Die bronteksouteur van In bushveld and desert: A game ranger's life was nie so aktief betrokke by die produksie van die doelteks nie, maar is deurgaans genader vir insette, om ander produksieagente se vrae te beantwoord en om betekenis te verhelder. Hy het plek-plek kort gedeeltes van die teks herskryf en, waar nodig, gedeeltes bygeskryf om die teks meer toeganklik vir die doelteksleser te maak. Uit die analises kan 'n mens sien dat die bronteksouteur in verskillende kapasiteite en tot verskeie mates betrokke kan wees by die produksieproses van literêre vertalings.

Daar kan ook gesien word dat die betrokkenheid van die bronteksouteur in al drie prosesse voordelig was om inhoudelike foute en verkeerde interpretasies uit te skakel en ander produksieagente se vrae te beantwoord. Dit bevestig die aanbeveling in Translation in pratice (Paul 2009) dat die bronteksouteur ideaal gesproke by die produksieproses van sy/haar vertalings betrokke moet wees. Daar is egter ook aangedui dat die betrokkenheid van die bronteksouteur in sekere opsigte nadelig vir die produksieproses kan wees, byvoorbeeld 
wanneer hy/sy die teks tot só 'n mate oorvertaal dat hy/sy as't ware die rol van die vertaler oorneem of ander produksieagente ondermyn, soos in die produksieproses van My name is Vaselinetjie gebeur het. Die uitgewer of opdraggewende redakteur kan in so 'n situasie as sosiale bemiddelaar help om 'n magswanbalans en konflik en wedywering wat daaruit spruit (vergelyk Bogic 2009), op te los sodat samewerking op 'n produktiewe wyse kan geskied.

Alhoewel al die produksieagente 'n beduidende rol in die produksie van 'n vertaling speel, wil dit wel voorkom of die bronteksouteur die produksieagent is wat die meeste status (simboliese kapitaal) in die produksieproses geniet en gevolglik ook die meeste mag het en invloed op die proses kan uitoefen. Steyn (2011a) sê die agente (insluitend die uitgewer) moet tydens die produksieproses van literêre vertalings daarvan bewus bly dat dit "die skrywer se boek [is wat] onder die skrywer se naam uitgegee" word. 'n Mens kan dus redeneer dat die bronteksouteur in sekere gevalle meer vryheid het om veranderinge aan die doelteksmanuskripte aan te bring as die vertaler/redigeerder/reviseur, ensovoorts aangesien hy/sy kreatief met sy/haar éie skepping kan omgaan. Silke (2011a) merk egter op dat dit kan gebeur dat 'n bronteksouteur te veel aan die teks "peuter", deur byvoorbeeld nadat die vertaling reeds afgehandel is, te wil byskryf, of regmaak wat hy/sy voel verkeerd was in die bronteks en dat daardie tipe teksveranderinge deur die bronteksouteur nie altyd 'n verbetering is nie. Die vertaler behoort gevolglik ook as 'n belangrike magsagent in die produksieproses beskou te word, aangesien hy/sy as die nuwe skepper van die teks in 'n nuwe taal en soms nuwe konteks beskou kan word.

Daar kan egter ook in die vertaalproses van 'n literêre werk die geleentheid vir selfvertaling (self-translation) geskep word, waar die bronteksouteur sy/haar manuskrip self volledig vertaal (verwys byvoorbeeld na Cordingley [2013], oor hierdie onderwerp). 'n Interessante opvolgstudie sal wees om te kyk na hoe die produksieprosesse van vertalings verskil waar die bronteksouteur as vertaler optree teenoor wanneer 'n vertaler die bronteks vertaal. Nog 'n interessante studie sal wees om die produksieprosesse van vertalings te vergelyk waar die bronteksouteur betrokke is teenoor waar die bronteksouteur glad nie geraadpleeg word tydens die proses nie en te kyk hoe die wisselwerking tussen agente, vertaalbesluite en die status van die onderskeie produksieagente in dié twee situasies verskil.

\section{Bronnelys}

Agorni, M. 2007. Locating systems and individuals in translation studies. In M. Wolf en A. Fukari (reds.). Constructing a sociology of translation. Amsterdam en Philadelphia: John Benjamins. pp. 123-134.

Bakkes, C. 2004a (1998). Die lang pad van Stoffel Mathysen. Kaapstad, Pretoria en Johannesburg: Human \& Rousseau.

Bakkes, C. 2004b. Stoffel by die afdraaipad. Kaapstad, Pretoria en Johannesburg: Human \& Rousseau.

Bakkes, C. 2006 (2000). Stoffel in die wildernis. Kaapstad en Pretoria: Human \& Rousseau.

Bakkes, C. 2007. Stoffel se veldnotas. Kaapstad en Pretoria: Human \& Rousseau. 
Bakkes, C. 2008. In bushveld and desert: A game ranger's life. Kaapstad: Human \& Rousseau.

Bakkes, C. 2011. Vraelys oor die produksieproses van In bushveld and desert: A game ranger's life. 30 Augustus 2011.

Berman, A. 2000 (1985). Translation and the trials of the foreign. In L. Venuti (red.). The translation studies reader. New York: Routledge. pp. 284-297.

Bogic, A. 2009. Rehabilitating Howard M. Parshley: A socio-historical study of the English translation of Beuvior's Le deuxième sexe, with Latour and Bourdieu. Ongepubliseerde magistertesis. Ottawa: University of Ottawa.

Bourdieu, P. 1986. The forms of capital. In J.E. Richardson (red.). Handbook of research for the sociology of education. (Vert. Richard Nice.) New York: Greenwood Press. pp. 46-58.

Bourdieu, P. 1993. The field of cultural production. (Vert. Claud du Verlie.) Cambridge en Oxford: Polity Press.

Bourdieu, P. 2002 (1977). Outline of a theory of practice. (Vert. Richard Nice.) Londen, New York en Melbourne: Cambridge University Press.

Bourdieu, P. 2005. The political field, the social field, and the journalistic field. In R. Benson, en E. Neveu (reds.). Bourdieu and the journalistic field. Cambridge en Malden: Polity Press. $25-47$.

Buzelin, H. 2007. Translations "in the making”. In M. Wolf en A. Fukari (reds.). Constructing a sociology of translation. Amsterdam en Philadelphia: John Benjamins. pp. 135-169.

Carstens, W.A.M. en Van de Poel, K. 2010. Teksredaksie. Stellenbosch: Sun Press.

Collins English Dictionary. 2014. Collins English Dictionary. Glasgow: HarperCollins. [Internet]. Beskikbaar: www.collinsdictionary.com. (6 September 2014).

Cooper, M. 2011. Vraelys oor die produksieproses van My name is Vaselinetjie. 22 Julie 2011.

Cordingley, A (red.). 2013. Self-Translation. Brokering originality in hybrid culture. New York: Bloomsbury USA Academic.

Genette, G. 1997. Paratexts: Thresholds of interpretation. (Vert. Jane E. Lewin.) Cambridge: Cambridge University Press.

Hermans, T. 1997 (1995). Translation as institution. In M. Snell-Hornby, S. Jettmarová en K. Kaindl (reds.). Translation as intercultural communication. Amsterdam en Philadelphia: John Benjamins. pp. 3-20. 
Hermans, T. 1999. Translation in systems. Descriptive and system-oriented approaches explained. Cornwall: St. Jerome.

International Association for Translation and Intercultural Studies (IATIS). 2014. Kongres: Collaborative translation: from antiquity to the Internet. 5-7 Junie, Parys, Frankryk.

Jansen, H. 2014. Author-Translator Collaboration: Questions to be asked. Ongepubliseerde kongresreferaat gelewer by Collaborative translation: from antiquity to the Internet. 5-7 Junie, Parys, Frankryk.

Kotze, A en Verhoef, M. 2001. Die teksversorger as spookskrywer: die teorie en professie onder die loep. Literator 22(2): 77-90.

Lefevere, A. 1992. Translation, rewriting, and the manipulation of literary fame. Londen en New York: Routledge.

Letawe, C. 2014. Günter Grass et ses traducteurs: de la dynamique collaborative au dispositive de contrôle? (Günter Grass and his translators: from collaboration to control?). Kongresreferaat gelewer by Collaborative translation: from antiquity to the Internet. 5-7 Junie, Parys, Frankryk.

Mossop, B. 2007. Editing and revising for translators. Manchester: St. Jerome.

Paul, G. (red.). 2009. Translation in practice. Champaign en Londen: Dalkey Archive Press.

Potgieter, A. 2011a. Vraelys oor die produksieproses van In bushveld and desert: A game ranger's life. 5 Augustus 2011.

Potgieter, A. 2011b. Vraelys oor die produksieproses van To hell with Cronjé. 22 Julie 2011.

Pym, A. 2011. Translation research terms: a tentative glossary for moments of perplexity and dispute. In A. Pym (red.). Translation research projects 3. Tarragona: International Studies Group. pp. 75-110. [Internet]. Beskikbaar: http://isg.urv.es/publicity/isg/publications/ trp_32011/pym.pdf (3 September 2014).

Silke, E. 2011a. Vraelys oor algemene aspekte rakende die produksieproses van literêre vertalings. 13 Julie 2011.

Silke, E. 2011b. Vraelys oor die produksieproses van My name is Vaselinetjie. 1 Junie 2011.

Spies, C. 2013. Agter die skerms van literêre vertalings: Christiaan Bakkes se kortverhale in Engels. Seminaar (middaguurgesprek) gelewer by die Departement Afrikaans en Nederlands, Universiteit Stellenbosch. 10 Oktober 2013, Stellenbosch, Suid-Afrika. 
Steyn, L. 2011a. Vraelys oor algemene aspekte rakende die produksieproses van literêre vertalings. 13 Julie 2011.

Steyn, L. 2011b. Vraelys oor die produksieproses van My name is Vaselinetjie. 18 Julie 2011.

Tarutz, J. 1992. Technical editing. The practical guide for editors and writers. Massachusetts: Addison-Wesley.

Toury, G. 2000. The nature and role of norms in translation. In L. Venuti (red.). The translation studies reader. Londen en New York: Routledge. pp. 205-218.

Van de Poel, K. 2003. From language practitioners to editors: The domain of text editing. In K. Van de Poel (red.). Antwerp papers in linguistics: Text editing - From a talent to a scientific discipline. Antwerpen: Universiteit Antwerpen. pp. 7-21.

Van Rensburg, A. 2012. Die impak van revisie op vertaalde eksamenvraestelle in 'n hoëronderwysomgewing, LitNet Akademies, Augustus: 9(2): 392-412. ]Internet]. Beskikbaar: http://www.litnet.co.za/Article/die-impak-van-revisie-op-vertaalde-eksamenvraestelle-in-nonderwysomgewing\#Artikel. (3 September 2014).

Venuti, L. 1995. The translator's invisibility. Londen: Routledge.

Von Meck, A. en Taaljaard, H. 2012. Vaselinetjie. [Verhoogproduksie]. Stellenbosch: Henry Mylne Produksies in samewerking met Woordfees. [9/03/2012].

Von Meck, A. 2009a. My name is Vaselinetjie. Kaapstad: Tafelberg.

Von Meck, A. 2009b (2004). Vaselinetjie. Kaapstad: Tafelberg.

Von Meck, A. 2011. Vraelys oor die produksieproses van My name is Vaselinetjie. 1 Augustus 2011.

Winterbach, I. 2007a (2002). Niggie. Kaapstad: Human \& Rousseau.

Winterbach, I. 2007b. To hell with Cronjé. Kaapstad: Human \& Rousseau.

Wolf, M. en Fukari, A. (reds.). 2007. Constructing a sociology of translation. Amsterdam en Philadelphia: John Benjamins.

Wolf, M. 2007. Introduction: The emergence of a sociology of translation. In M. Wolf en A. Fukari (reds.). Constructing a sociology of translation. Amsterdam en Philadelphia: John Benjamins. pp. 1-36. 